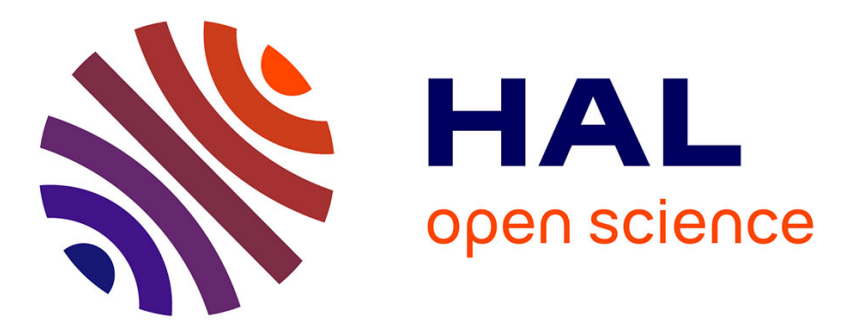

\title{
Enhanced responsiveness of Ghsr Q343X rats to ghrelin results in enhanced adiposity without increased appetite
} Yacine Chebani, Candice Marion, Philippe Zizzari, Khadidja Chettab, Marie

Pastor, Marie Korostelev, David Geny, Jacques Epelbaum, Virginie Tolle, Séverine Morisset-Lopez, et al.

\section{To cite this version:}

Yacine Chebani, Candice Marion, Philippe Zizzari, Khadidja Chettab, Marie Pastor, et al.. Enhanced responsiveness of Ghsr Q343X rats to ghrelin results in enhanced adiposity without increased appetite. Science Signaling, 2016, 9 (424), pp.ra39. 10.1126/scisignal.aae0374 . inserm-01463897

\section{HAL Id: inserm-01463897 https://www.hal.inserm.fr/inserm-01463897}

Submitted on 9 Feb 2017

HAL is a multi-disciplinary open access archive for the deposit and dissemination of scientific research documents, whether they are published or not. The documents may come from teaching and research institutions in France or abroad, or from public or private research centers.
L'archive ouverte pluridisciplinaire HAL, est destinée au dépôt et à la diffusion de documents scientifiques de niveau recherche, publiés ou non, émanant des établissements d'enseignement et de recherche français ou étrangers, des laboratoires publics ou privés. 


\section{Science Signaling}

\section{Accepted version}

This is the author's version of the work. It is posted here by permission of the AAAS for personal use, not for redistribution. The definitive version was published in Science Signaling 9(424), ra39. doi:10.1126/scisignal.aae0374. http://stke.sciencemag.org/content/9/424/ra39

\section{Enhanced responsiveness of $G h s r^{\mathrm{Q343X}}$ rats to ghrelin results in enhanced adiposity without increased appetite}

Yacine Chebani ${ }^{1} \dagger$, Candice Marion ${ }^{1} \dagger$, Philippe Zizzari ${ }^{1} \dagger$, Khadidja Chettab ${ }^{1}$, Marie Pastor ${ }^{1}$, Marie Korostelev ${ }^{1}$, David Geny ${ }^{1}$, Jacques Epelbaum ${ }^{1,2}$, Virginie Tolle ${ }^{1}$, Séverine MorissetLopez $^{3}$ and Jacques Pantel ${ }^{1,4 *}$

\section{Affiliations:}

${ }^{1}$ INSERM, Université Paris Descartes, Sorbonne Paris Cité, UMR-S 894, Centre de Psychiatrie \& Neurosciences, 75014 Paris, France

${ }^{2}$ CNRS, MNHN, UMR 7179, Mécanismes adaptatifs et évolution, 91800 Brunoy, France

${ }^{3}$ Centre de Biophysique Moléculaire, CNRS, UPR 4301, Université d'Orléans, 45071 Orléans, France

${ }^{4}$ Department of Molecular Physiology and Biophysics, Vanderbilt School of Medicine, Nashville, TN 37232, USA

$\dagger$ These authors contributed equally to this work

* To whom correspondence should be addressed: jacques.pantel@ inserm.fr 


\begin{abstract}
$\underline{\text { Abstract }}$
The ability of the gut hormone ghrelin to promote positive energy balance is mediated by the growth hormone secretagogue receptor (GHSR). GHSR is a G protein-coupled receptor (GPCR) that is found centrally and peripherally and that can signal in a ligand-independent manner basally or when heterodimerized with other GPCRs. However, current Ghsr knockout models cannot dissect ghrelindependent and -independent signaling, precluding assessment of the physiological importance of these signaling pathways. An animal model carrying a Ghsr mutation that preserves GHSR cell surface abundance, but selectively alters GHSR signaling, would be a useful tool to decipher GHSR signaling in vivo. We used rats with the $G h s r^{\mathrm{Q} 343 \mathrm{X}}$ mutation $\left(G h s r^{\mathrm{M} / \mathrm{M}}\right)$, which is predicted to delete the distal part of the GHSR C-terminus tail, a domain critical for the signal termination processes of receptor internalization and $\beta$-arrestin recruitment. In cells, the Q343X GHSR mutant showed enhanced ligandinduced G protein-dependent signaling and blunted activity of processes involved in GPCR signal termination. $G h s r^{\mathrm{M} / \mathrm{M}}$ rats displayed enhanced responses to submaximal doses of ghrelin or GHSR agonist. Moreover, Ghsr ${ }^{\mathrm{M} / \mathrm{M}}$ rats had a more stable body weight under caloric restriction, a condition that increases endogenous ghrelin tone, whereas under standard housing conditions, $G h s r^{\mathrm{M} / \mathrm{M}}$ rats showed increased body weight, adiposity and reduced glucose tolerance. Overall, our data stresses the physiological role of the distal domain of GHSR C-terminus as a suppressor of ghrelin sensitivity and we propose using the $G h s r^{\mathrm{M} / \mathrm{M}}$ rat as a physiological model of gain-of-function in Ghsr to identify treatments for obesity-related conditions.
\end{abstract}




\section{$\underline{\text { Introduction }}$}

Ghrelin is a pleiotropic hormone secreted by the stomach (1) that promotes food-seeking behaviors and a positive energy balance by means of several central mechanisms involving hedonic (2-4) and energy homeostasis circuits (5-8). To date, the growth hormone secretagogue receptor (GHSR), a G protein (heterotrimeric guanine nucleotide-binding protein)-coupled receptor (GPCR) found peripherally and in several brain regions, is the sole receptor that mediates the biological effects of ghrelin (9-11). In cellular systems, GHSR can signal in response to ghrelin through $\mathrm{G}_{\alpha \mathrm{q} / 11}$-dependent $(1,12,13)$ or $\mathrm{G}_{\alpha \mathrm{i}}$-dependent pathways (14). In addition, GHSR can signal in the absence of ligand because of high constitutive activity $(12,15)$ and can selectively modulate dopamine signaling through heterodimerization with dopamine receptors DRD1 and DRD2 $(16,17)$. Although GHSR is internalized constitutively and in response to ghrelin, ligand binding is necessary to trigger $\beta$ - $\operatorname{arrestin}_{2}$ recruitment. Both processes require the receptor C-terminal tail, a domain comprising several putative phosphorylation sites $(18,19)$. Thus far, however, the lack of understanding of the physiological importance of these ghrelin-dependent and ghrelinindependent GHSR signaling features precludes efficient drug targeting (20).

The hormone ghrelin and its receptor induce potent biological responses such as food intake, adipogenesis, and growth hormone secretion, but the physiological roles of both the hormone and receptor still remain incompletely defined by currently available genetic studies (21). GHSR promotes somatic growth in humans, presumably through growth hormone secretagogue properties, but its association with obesity risk is inconsistent (22-26) although dysregulated amounts of the orexigenic acyl ghrelin correlate with obesity features associated with a common single-nucleotide polymorphism at the FTO locus (27). Although $\mathrm{Ghsr}^{-/}$mice consistently demonstrate a decreased motivation for hedonic eating $(28,29)$ these animals do not clearly show altered body weight or energy intake (10,30-32) suggesting that GHSR is 
not a key regulator of food intake or body weight or alternatively, that GHSR knockdown induces a compensatory response to maintain normal phagic drive and body weight.

To assess the physiological significance of GHSR signaling and possibly circumvent the caveats related to Ghsr knockout, we hypothesized that a rodent model carrying a Ghsr mutation that maintains GHSR cell surface abundance but alters its signaling properties would provide insight into the role of GHSR. Accordingly, we studied a rat line bearing a $G h s r$ mutant $\left(G h s r^{\mathrm{Q} 343 \mathrm{X}}\right)$ that has a premature termination codon that is predicted to delete most of the putative phosphorylation sites in the distal half of the $\mathrm{C}$ terminus domain of this GPCR (GHSR-Q343X) (33), a domain involved in signal termination. Using in vitro and in vivo approaches, we revealed that the $G h s r^{\mathrm{Q} 343 \mathrm{X}}$ allele resulted in a gain of function that altered body weight and glucose homeostasis in Ghsr mutant rats. Our observations suggest that the key physiological role of the distal part of GHSR C terminus is to suppress ghrelin sensitivity and that Ghsr mutant rats can be used to explore the importance of GHSR signaling in vivo and identify treatments for obesity-related conditions. 


\section{$\underline{\text { Results }}$}

\section{The Q343X mutation in GHSR impairs ligand-induced internalization and $\beta$-arrestin recruitment $_{\text {rito }}$ in HEK cells}

Because altering the C-terminal tail of GHSR modifies receptor trafficking patterns (18), we hypothesized that the C-terminal truncation predicted by the Q343X mutation (Fig. 1A) would impair GHSR internalization. To investigate the consequences of this mutation on receptor trafficking, we determined the cell surface abundance of hemagglutinin (HA)-tagged wild-type or mutant rat GHSR isoforms. As expected, ghrelin triggered an acute decrease of cell surface abundance of the wild-type isoform (40\% internalization at $20 \mathrm{~min}$ ) followed by a progressive replenishment after $180 \mathrm{~min}$ (Fig. 1B). In contrast, the cell surface abundance of the mutant isoform did not differ over time compared to unstimulated conditions and was significantly greater than the wild-type isoform, supporting an impairment of ghrelininduced internalization of this truncated GPCR.

$\beta$-arrestin 2 recruitment by GHSR requires the C-terminal tail, and presumably the phosphorylation patterns of Ser and Thr residues in this domain $(18,19)$. Because most putative S/T phosphorylation sites in the $\mathrm{C}$ terminus are missing in the $\mathrm{Q} 343 \mathrm{X}$ mutant, it seemed likely that $\beta$-arrestin recruitment to the mutant receptor would be impaired. Confocal imaging showed that in response to a maximum dose of ghrelin, $\beta$-arrestin 2 -enhanced yellow fluorescent protein (eYFP) translocated to the cell surface in cells expressing wild-type GHSR but not in those expressing the mutant GHSR (Fig. 1C). Bioluminescence resonance energy transfer (BRET) analysis showed that $\beta$-arrestin ${ }_{2}$ was recruited to a much lesser extent to the Q343X mutant than to wild-type GHSR (Fig. 1D). These results indicate that the distal C-terminal residues are not required for proper cell surface presentation, but that they play a key role in ghrelininduced GHSR internalization and $\beta$ - $\operatorname{arrestin}_{2}$ recruitment. 


\section{The Q343X mutation in GHSR enhances ligand-induced responses in HEK cells}

GHSR signals through $\mathrm{G}_{\alpha q / 11}$, which activates a phospholipase $\mathrm{C}$ (PLC)-Ca ${ }^{2+}$-dependent signaling pathway $(1,12,13)$. Therefore, to explore the functional consequences of the GHSR mutation on agonist responses, we performed calcium flux experiments. The concentration-response curve in response to ghrelin was shifted to the left in cells expressing the GHSR-Q343X mutant (Fig. 2A), which indicates increased potency for ghrelin. In addition, the maximum effect of ghrelin was increased in cells expressing the Q343X mutant, suggesting improved ghrelin efficacy. Cell pretreatment with the PLC inhibitor U73122 inhibited the calcium response to ghrelin to a similar extent in wild-type GHSR- and GHSR-Q343X mutant-expressing cells (Fig. 2B). In cells expressing either the wild-type or Q343X mutant receptor, the $\mathrm{G}_{\mathrm{i} / \mathrm{o}}$ inhibitor pertussis toxin did not inhibit ghrelin-induced $\mathrm{Ca}^{2+}$ mobilization, which is characteristic of a $\mathrm{G}_{\alpha q / 11}$-PLC-mediated response. Similar to ghrelin, calcium flux experiments revealed an enhanced response of cells expressing the mutant GHSR compared to those expressing wild-type GHSR to the GHSR agonist hexarelin (Fig. 2C). Thus, the enhanced activity of the GHSR-Q343X mutant was not ligand-specific. These observations support the notion that the Q343X mutation in rat GHSR is a ghrelin-dependent gain-of-function mutation associated with increased activation of $\mathrm{G}_{\alpha \mathrm{q} / 11}$ signaling.

Second, we used the serum response element (SRE) reporter gene assay (34) to explore the functional consequences of the Q343X mutation in GHSR on distinct signaling pathways involving both ligandindependent and ligand-dependent signaling. Compared to cells expressing wild-type GHSR, those expressing the GHSR-Q343X mutant produced a similar basal signal but a greater maximal ghrelin response (Fig. 2D). However, $\mathrm{EC}_{50} \mathrm{~s}$ were not significantly different. In the same assay, the mitogenactivated protein kinase (MAPK) inhibitor SL327 or the Ras homolog gene family, member A (RhoA)Rho-associated protein kinase (ROCK) pathway inhibitor GSK269962 blocked ghrelin-induced SRE responses in GHSR-Q343X or wild-type GHSR cells to similar extents (Fig. 2E), suggesting that the Q343X mutation in rat GHSR increases ghrelin-dependent MAPK and RhoA-ROCK signaling. 


\section{$G h s r^{\mathrm{M} / \mathrm{M}}$ rats are hypersensitive to exogenous ghrelin or agonist}

The hypothalamus is a key target of ghrelin (21). To pharmacologically probe in vivo GHSR responsiveness, we selected two key ghrelin-induced responses, growth hormone secretion and food intake, that are mediated by GHSR signaling in hypothalamic neurons $(7,35)$. We used a two ghrelin injection protocol to explore GHSR responsiveness and desensitization in freely moving Ghsr mutant $\left(G h s r^{\mathrm{M} / \mathrm{M}}\right)$ or wild-type (Ghsr $\left.r^{\mathrm{WT} / \mathrm{WT}}\right)$ littermates (Fig. 3A to D). $G h s r^{\mathrm{M} / \mathrm{M}}$ rats released growth hormone in response to a lower intravenous ghrelin dose (Fig. 3E), although the genotypes did not differ at the dose commonly used to trigger a maximum release of growth hormone $(10 \mu \mathrm{g})$. To explore the pattern of desensitization of GHSR in vivo, growth hormone release was examined after a second intravenous ghrelin injection $(10 \mu \mathrm{g})$ at $60 \mathrm{~min}\left(\mathrm{t}_{60}\right)$ as previously documented (36). Regardless of genotypes, as expected, growth hormone peak intensity in response to the second ghrelin injection was inversely proportional to the peak intensity after the first injection (Fig. 3A to D). However, decreased growth hormone release occurred at a lower ghrelin dose in $G h s r^{\mathrm{M} / \mathrm{M}}$ rats compared to $G h s r^{\mathrm{WT} / \mathrm{WT}}$ rats (Fig. 3F), supporting a lower threshold of desensitization.

We monitored food intake in rats injected with a maximum dose of the GHSR agonist hexarelin (Fig. 3G). Hexarelin stimulated food intake similarly in $G h s r^{\mathrm{M} / \mathrm{M}}$ and $G h s r^{\mathrm{WT} / \mathrm{WT}}$ rats, therefore showing that $G h s r^{\mathrm{M} / \mathrm{M}}$ rats had a normal agonist-induced food intake response. To further explore GHSR responsiveness in these mutant rats, we performed a dose-response analysis of the orexigenic effects of hexarelin in a different cohort of male rats. In $G h s r^{\mathrm{M} / \mathrm{M}}$ rats, the dose-response curve was shifted leftward compared to Ghsr ${ }^{\mathrm{WT} / \mathrm{WT}}$ rats (Fig. 3H), indicating that hexarelin had enhanced potency. This observation supports that $G h s r^{\mathrm{M} / \mathrm{M}}$ rats have enhanced GHSR sensitivity.

\section{$G h s r^{\mathrm{M} / \mathrm{M}}$ rats show increased sensitivity to endogenous acyl ghrelin}

To test whether $G h s r^{\mathrm{M} / \mathrm{M}}$ rats were more responsive to endogenous ghrelin, we monitored body weight and glycemia in $G h s r^{\mathrm{M} / \mathrm{M}}$ and $G h s r^{\mathrm{WT} / \mathrm{WT}}$ rats subjected to caloric restriction, which increases ghrelin tone. $G h s r^{\mathrm{M} / \mathrm{M}}$ rats lost significantly less weight compared to wild-type littermates proportionally to their initial 
body weight (Fig. 4A, top panel). Glucose concentrations were decreased for most time points during caloric restriction and were restored to initial values upon refeeding for both genotypes (Fig. 4A middle panel). Concentrations of growth hormone, which participates in ghrelin- and GHSR-mediated glycemic control during severe caloric restriction, did not differ between genotypes (Fig. 4A lower panel).

Circulating concentrations of acyl and des-acyl ghrelin isoforms increased between ad libitum [day $0\left(\mathrm{~d}_{0}\right)$ ] and caloric restriction conditions $\left(\mathrm{d}_{1}\right.$ and $\left.\mathrm{d}_{16}\right)$, although to a lesser extent in $G h s r^{\mathrm{M} / \mathrm{M}}$ compared to $G h s r^{\mathrm{WT} / \mathrm{WT}}$ rats. These concentrations returned to initial values at refeeding $\left(\mathrm{d}_{17}\right)($ Fig. 4B, upper and middle panels). However, the acyl ghrelin/total ghrelin ratio was not significantly different between genotypes across the experiment (Fig. 4B, lower panel). Collectively, these results suggest that the mutant GHSR encoded by the $G h s r^{0343 X}$ allele helps maintain body weight during an episode of chronic caloric restriction, which is consistent with the role of ghrelin in promoting a positive energy balance. Because acyl ghrelin concentrations were not increased in $G h s r^{\mathrm{M} / \mathrm{M}}$ rats, we presume that this protective effect was related to the increased sensitivity to acyl ghrelin.

\section{$G h s r^{\mathrm{M} / M}$ rats show increased body weight and adiposity and decreased glucose tolerance}

To decipher the phenotypic consequences associated with chronically enhanced sensitivity to endogenous ghrelin in $G h s r^{\mathrm{M} / \mathrm{M}}$ rats, we monitored body weight, body composition, and energy intake in $G h s r^{\mathrm{M} / \mathrm{M}}$ and wild-type ad libitum fed rats on standard chow. Although weight was comparable at 4 weeks of age (after weaning), at 3 months $G h s r^{\mathrm{M} / \mathrm{M}}$ rats gained more body weight than Ghsr ${ }^{\mathrm{WT} / \mathrm{WT}}$ rats (Figs. 5A and B). Iterative body weight measurements on a subgroup of animals revealed that the genotype effect was stable at adulthood in standard housing conditions (Fig. 5C) although nose-to-anus measurements were not different between genotypes (Fig. 5D). Body composition, as assessed by quantitative nuclear magnetic resonance, revealed greater fat mass in $G h s r^{\mathrm{M} / \mathrm{M}}$ rats than in wild-type littermates but no changes in lean mass (Fig. 5E and F). Plasma leptin concentrations were increased in male $G h s r^{\mathrm{M} / \mathrm{M}}$ rats in agreement with increased fat mass (Fig. 5G). The increased body weight and adiposity were consistent with the increased food intake of $G h s r^{\mathrm{M} / \mathrm{M}}$ rats (Fig. 5H). However, chow intake did not differ when 
normalized to body weight, suggesting that $G h s r^{\mathrm{M} / \mathrm{M}}$ rats were eating proportionally to their body weight (Fig. 5I). Finally, since genetic deletion of the components in the ghrelin-GHSR pathway is believed to improve glucose tolerance (37), we measured glucose and insulin concentrations before and after a dextrose load. The insulin resistance index HOMA-IR (homeostasis model assessment insulin resistance) was increased in mutant rats compared to wild-type littermates (Fig. 5J), an observation that was consistent with the higher basal glycemia in fasted $G h s r^{\mathrm{M} / \mathrm{M}}$ rats compared to $G h s r^{\mathrm{WT} / \mathrm{WT}}$ rats (Fig. 5K). After an oral glucose load, $G h s r^{\mathrm{M} / \mathrm{M}}$ rats had increased glucose concentrations compared to $G h s r^{\mathrm{WT} / \mathrm{WT}}$ rats (Fig. 5K). Insulin responses were similar among genotypes (Fig. 5L). Hence, these observations illustrating a decreased glucose tolerance in $G h s r^{\mathrm{M} / \mathrm{M}}$ rats likely reflect decreased insulin sensitivity in these animals. These observations support that increased ghrelin sensitivity in $G h s r^{\mathrm{M} / \mathrm{M}}$ rats increases body weight and adiposity and decreases glucose tolerance without affecting daily food intake. 


\section{$\underline{\text { Discussion }}$}

Our in vitro and in vivo results support the hypothesis that mutant rats carrying the $G h s r^{\mathrm{Q} 343 \mathrm{X}}$ allele are a model of gain of function for Ghsr due to enhanced sensitivity to endogenous ghrelin. In support of this hypothesis, HEK cells expressing the GHSR-Q343X isoform that lacks the distal part of its C-terminal tail, a domain critical for receptor internalization and $\beta$-arrestin recruitment, displayed greater ligandinduced G protein-dependent signaling and blunted GPCR signal termination relative to wild-type GHSRexpressing HEK cells. Furthermore, $G h s r^{\mathrm{M} / \mathrm{M}}$ rats, which bear the mutant allele, displayed enhanced responses to submaximal doses of ghrelin or agonist and maintained body weight in a state of increased endogenous ghrelin tone (namely, caloric restriction). In standard housing conditions $G h s r^{\mathrm{M} / \mathrm{M}}$ rats showed increased body weight and adiposity and reduced glucose tolerance. As proposed in the schematic model (Fig. 6), our observations suggest that the C-terminal distal domain of the GHSR acts as a negative regulator of ghrelin receptor sensitivity in vivo through $\beta$-arrestin recruitment and receptor internalization, and stress the key physiological role of GHSR sensitivity in body weight, adiposity, and glucose homeostasis control independently of a role in food intake.

Previous work in cellular systems supported a critical role for the GHSR C-terminal domain in receptor trafficking $(18,19)$. Here, several lines of evidence support the notion that the distal part of the C-terminal tail of GHSR inhibits GHSR function. The GHSR-Q343X mutant lacks most of the putative Ser/Thr phosphorylation sites that are located in the distal $\mathrm{C}$ terminus and displayed impaired $\beta$-arrestin 2 recruitment and internalization in response to ghrelin stimulation in HEK cells. These observations are consistent with previous studies showing that both of these cellular processes require the C-terminal tail.

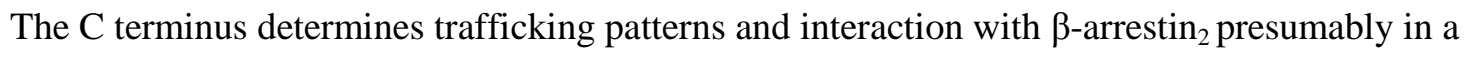
phosphorylation-dependent manner $(18,19)$. The Q343X mutation also increased agonist-induced $\mathrm{Ca}^{2+}$ mobilization through the $\mathrm{G}_{\alpha \mathrm{\alpha} / 11}$-PLC pathway and SRE responses through the MAPK and RhoA 
pathways. Because $\beta$-arrestin plays an important role in $\mathrm{G}$ protein signal termination (38), the enhanced ghrelin responsiveness of the Q343X mutant could be explained by its defective $\beta$-arrestin recruitment. This hypothesis is supported by another mutant GHSR (GHSR-P148A), which cannot interact with $\beta$ $\operatorname{arrestin}_{2}$ but is still internalized in response to agonist stimulation, and shows increased agonist-induced $\mathrm{G}$ protein-dependent signaling (19). In the absence of ligand, however, the wild-type GHSR and GHSRQ343X isoforms showed similar basal MAPK- and RhoA-dependent signaling, indicating that the Q343X mutation does not modify constitutive signaling.

Second, we observed enhanced sensitivity of the mutant GHSR in vivo to submaximal ghrelin or agonist doses peripherally injected in $\mathrm{Ghsr}^{\mathrm{M} / \mathrm{M}}$ rats (as assessed by growth hormone secretion and food intake). Thus, the orexigenic and growth hormone secretagogue properties of ghrelin are mediated by G protein signaling. In addition, on the basis of our cellular results, one might speculate that these biological responses may not require $\beta$-arrestin-dependent signaling pathways. The $\mathrm{C}$ terminus of various GPCRs influence functional responses through differential patterns of phosphorylation (39). On the other hand, in vivo, GHSR- $\beta$-arrestin interaction in target cells may not be solely determined by phosphorylation of GHSR C-terminal tail, and we cannot exclude that other GHSR domains may participate to $\beta$-arrestin recruitment and stabilization. In particular, a study by Evron et al. (19) has implicated the intracellular loop 2 of GHSR as a critical domain that regulates the stability of the GHSR- $\beta$-arrestin complex. Regardless, the GHSR-Q343X mutant, in addition to affecting G protein signaling, is likely to affect ghrelin responses involving $\mathrm{G}$ protein-independent signaling (including $\beta$-arrestin), the extent of which will need to be deciphered in future studies.

Third, the physiological enhancement of endogenous ghrelin tone during caloric restriction was associated with improved body weight maintenance in $G h s r^{\mathrm{M} / \mathrm{M}}$ rats compared to wild-type littermates. This further establishes the role of ghrelin in promoting a positive energy balance. Of note, circulating acyl ghrelin was not increased in $G h s r^{\mathrm{M} / \mathrm{M}}$ rats compared to $G h s r^{\mathrm{WT} / \mathrm{WT}}$ rats, therefore supporting enhanced 
sensitivity to endogenous ghrelin in $G h s r^{\mathrm{M} / \mathrm{M}}$ rats. Overall, these observations underscore that the gain-offunction mechanism established in cellular systems is relevant in vivo to several key hypothalamic actions of ghrelin-GHSR and validate Ghsr mutant rats as a model showing hypersensitivity to endogenous ghrelin. Also, more broadly, these observations are in accordance with other examples disclosing the role of C-terminal phosphorylation motifs in regulating negatively GPCRs in vivo (40, 41).

The present $G h s r^{\mathrm{M} / \mathrm{M}}$ rat model differs from current models developed to explore the physiological significance of ghrelin-GHSR function (42). First, circulating acyl and des-acyl ghrelin concentrations are apparently unaltered in $G h s r^{\mathrm{M} / \mathrm{M}}$ rats as opposed to models targeting Ghrl or Goat genes. Second, in contrast to Ghsr knockout animals, the $G h s r^{\mathrm{Q} 343 \mathrm{X}}$ allele encodes a mutant GHSR with proper functional responses in vitro and in vivo. Moreover, $G h s r^{\mathrm{M} / \mathrm{M}}$ rats may lack compensatory responses that may occur in $G h s r^{-/}$mice. We therefore suggest that this 'physiological' gain of function in Ghsr model could serve as a more appropriate model to explore the consequences of enhanced GHSR signaling in response to endogenous ghrelin fluctuations that result from physiological or pathological conditions. The elucidation of the physiological role of Ghsr using genetic invalidation strategies has been hampered by the modest and inconsistent effects on body weight or food intake modifications $(10,30-32)$. Although young $G h s r^{--}$ mice do not have a phenotype, aged $G h s r^{-/-}$mice show decreased body weight and decreased insulin resistance relative to wild-type mice (37). Here, adult $G h s r^{\mathrm{M} / \mathrm{M}}$ rats showed increased body weight and adiposity and decreased glucose tolerance, a phenotype opposite of aged $G h s r^{--}$mice (37). Rats with enhanced ghrelin signaling therefore recapitulate a pre-obesity state.

The GHSR mediates the potent orexigenic and growth hormone secretagogue effects of ghrelin (10), but the physiological importance of these properties has been challenged by most studies using mice with genetic ablations of various components of the ghrelin system (21). Ghsr ${ }^{\mathrm{M} / \mathrm{M}}$ rats, which have enhanced ghrelin sensitivity and normal plasma ghrelin concentrations, should therefore be a useful model to assess the physiological relevance of these properties. Although $G h s r^{\mathrm{M} / \mathrm{M}}$ rats showed enhanced growth hormone 
secretion and food intake to submaximal doses of agonist, these animals are neither giants nor hyperphagic. The present data, which overcome the argument of compensatory mechanisms associated with knockout mice (42), are consistent with a study that documented no appetite loss in mice whose ghrelin-producing cells were ablated at adulthood (43). Moreover, in both control and ghrelin cell-ablated mice, only supraphysiological doses of ghrelin could stimulate food intake. Collectively, these observations support that ghrelin is not a regulator of food intake in rodents in standard housing conditions. In contrast, our results emphasized the role of ghrelin in fat storage, which is in agreement with previous observations supporting that both adipogenic and orexigenic roles of ghrelin are independently regulated $(8,44)$. On the other hand, our observations are consistent with those in $G h s r^{-/-}$ mice supporting that ghrelin-GHSR signal is not a key contributor to somatic growth in rodents (10). In contrast, several genetic studies support the role of GHSR as a physiological contributor in humans both to the adult height variance among individuals (23-25) and to the nosology of somatic growth disorders $(22,45,46)$.

As opposed to the present study, previous studies using $G h s r^{\mathrm{M} / \mathrm{M}}$ rats did not detect body weight differences, which could be explained by the small numbers of rats used $(33,47)$. Furthermore, the heterogeneous observations emerging from these studies focusing on the role of GHSR in reward, learning and memory, gastrointestinal motility, or feeding behavior are apparently opposed to the present mechanism (33, 47, 48). As for the observation on feeding behavior, Bülbul et al. (33) used 24-hourfasted rats compared to ad libitum fed animals in the present study. Because their particular experimental setting explored the ghrelin response in a more stressful condition compared to ad libitum fed animals and disadvantages its orexigenic effects due to spontaneous refeeding, we assume that the conclusions drawn from this experiment should therefore be taken cautiously. In contrast, the observations related to extrahypothalamic actions of GHSR are somewhat unexpected because of the gain-of-function nature of the $G h s r^{\mathrm{Q} 343 \mathrm{X}}$ mutant. To reconcile such apparently contradictory observations, we speculate that the altered signaling or trafficking features associated with the GHSR-Q343X isoform might impair ghrelin 
responses through non-G protein signaling pathways of so far unknown biological importance or alternatively impair responses of other GPCRs in the context of heterodimers as has been disclosed for GHSR $(16,17)$. Overall, we propose that $G h s r^{\mathrm{Q} 343 \mathrm{X}}$ rats are a promising tool to specifically decode GHSR signaling in biological functions. 


\section{$\underline{\text { Materials and Methods }}$}

\section{Cell culture, plasmids and transfections}

Human embryonic kidney cells (HEK293) were cultured in high glucose DMEM supplemented with 10\% heat-inactivated foetal bovine serum and $100 \mathrm{mg} / \mathrm{ml}$ of penicillin-streptomycin (PS) in a humidified atmosphere of $95 \%$ air and $5 \% \mathrm{CO}_{2}$ at $37^{\circ} \mathrm{C}$. Cells were transfected with Lipofectamine 2000 (Life Technologies) according to the manufacturer's recommendations. A cDNA sequence of wild-type rat GHSR1a served as a PCR template to generate the following plasmids: 3xHA-rGHSR-WT and 3xHArGHSR-WT-rLuc in the vector pcDNA3.1. Plasmids containing the GHSR-Q343X mutation were generated from the corresponding wild-type plasmids using the Quickchange site directed mutagenesis kit (Agilent). HEK293 clones stably expressing 3xHA-rGHSR-WT or 3xHA-rGHSR-Q343X were obtained after 2 weeks of geneticin selection $(700 \mathrm{ng} / \mathrm{ml})$. Two individual clones were selected for future experiments on the basis of a similar cell surface abundance of HA-GHSR as determined by ELISA.

\section{Assessment of HA-GHSR cell surface abundance}

HEK293 cells expressing HA-tagged rat GHSR or native HEK293 cells as control were seeded at $4 \times 10^{4}$ cells/well in clear 96-well poly-L-lysine coated plates and cultured overnight. Cells treated by vehicle or ghrelin were washed with PBS and then fixed in $4 \%$ paraformaldehyde for 15 minutes and incubated in blocking solution with 5\% goat serum and 1\% BSA in PBS for $1 \mathrm{~h}$ at room temperature. Cells were incubated for $1 \mathrm{~h}$ at $37^{\circ} \mathrm{C}$ with anti-HA rabbit antibody (Life Technologies) at a 1:500 dilution in 1\% BSA/PBS. After three PBS washes, cells were incubated $1 \mathrm{~h}$ at room temperature with anti-rabbit horseradish peroxidase-conjugated goat antibody (Dako) at a 1:4000 dilution in 1\% BSA/PBS. After three PBS washes, the immunoreactivity was revealed after a 25-min incubation with o-phenylenediamine (Invitrogen) diluted in citrate-phosphate buffer, $\mathrm{pH} 5.0$, containing $0.03 \%$ hydrogen peroxide; the reaction was stopped by addition of 3M sulfuric acid. Absorbance was read at $492 \mathrm{~nm}$ with a background 
subtraction at $620 \mathrm{~nm}$ in a microplate spectrophotometer (Multiskan EX, Thermo Scientific). Net signal was defined as the signal of HA-GHSR-expressing cells minus the signal of control cells.

\section{Calcium mobilization assays}

Intracellular free calcium fluctuations were measured using the calcium-sensitive fluorescent dye Fluo-4 AM (Life Technologies). HEK293 cells stably expressing wild-type rat GHSR or the Q343X mutant were seeded the day before experiments were performed at $3.5 \times 10^{4}$ cells/well in black 96-well plates with clear poly-L-lysine coated bottoms. For inhibition assays, cells were incubated overnight in medium with U73122 (10 $\mu \mathrm{M}$; Sigma Aldrich), pertussis toxin (PTX ; 200ng/mL ; Tocris Bioscience) or DMSO (0.2\%) control. After a HBSS wash, cells were incubated $1 \mathrm{~h}$ at $37^{\circ} \mathrm{C}, 5 \% \mathrm{CO}_{2}$ with $3 \mu \mathrm{M}$ Fluo- 4 AM diluted in 0.02\% Pluronic (Life Technologies) in loading buffer, HBSS with $20 \mathrm{mM}$ HEPES and $2.5 \mathrm{mM}$ probenecid (Sigma). Cells were then washed with HBSS and incubated in loading buffer \pm inhibitors. The fluorescent signal recording was performed at $37^{\circ} \mathrm{C}$ in a Mithras LB 940 microplate fluorometer (Berthold Technologies) with excitation/emission wavelengths of $485 / 525 \mathrm{~nm}$. After removing the nonspecific signal (vehicle), the calcium response was defined as ligand-induced fluorescent peak expressed as percentage of the maximum response after cell lysis.

\section{SRE reporter gene assays}

To study the ligand-induced transcriptional activity of rat GHSR isoforms, HEK293 cells expressing a SRE consensus sequence coupled to a luciferase reporter gene (pSRE, Agilent) with WT- or Q343XrGHSR were cultured in the presence or the absence of ligand. Cells were seeded at $2 \times 10^{4}$ cells/well in white 96-well plates with poly-L-lysine coated bottoms. The next day, cells were transiently transfected with rGHSR (WT or Q343X; $2.5 \mathrm{ng} /$ well) and pSRE (100 ng/well) plasmids for $6 \mathrm{~h}$ at $37^{\circ} \mathrm{C}$. Cells were serum-starved overnight in DMEM/PS (1\%) supplemented with HEPES buffer (10 mM) and serum replacement medium (Sigma Aldrich). The following day, rat ghrelin or vehicle was added, and cells were incubated at $37^{\circ} \mathrm{C}$ for $5 \mathrm{~h}$. For concentration-response assays, cells were incubated with increasing 
concentrations of ghrelin $\left(1 \times 10^{-11}\right.$ to $\left.3 \times 10^{-7} \mathrm{M}\right)$. For inhibition assays, cells were pre-incubated with PTX (200 ng/mL) overnight, or with DMSO (0.1\%), SL327 (10 $\mu$ M; Tocris Bioscience), or GSK269962 ( $5 \mu \mathrm{M}$; Tocris Bioscience) for $30 \mathrm{~min}$ before ghrelin addition $\left(3 \times 10^{-7} \mathrm{M}\right)$. After a PBS wash, cell lysates obtained with cell culture lysis reagent (Promega) were assayed for luminometric measurements using the luciferase assay reagent (Promega) in a Mithras LB 940 microplate reader (Berthold Technologies). To rule out any differences in cell number, total protein concentration was determined using Micro BCA Protein Assay Kit (Thermo Scientific).

\section{Bioluminescence Resonance Energy Transfer (BRET) assay}

To assess the ghrelin-induced interaction between $\beta$-arrestin and wild-type GHSR or the Q343X mutant, BRET was measured in HEK293 cells that were transiently transfected in 6-well plate with BRET pairs (rGHSR-WT-rLuc or rGHSR-Q343X-rLuc and $\beta$-arrestin ${ }_{2}$-eYFP) or with donor alone (GHSR-rLuc) and transferred at $3.5 \times 10^{4}$ cells/well in white 96 -well plates. $48 \mathrm{~h}$ after transfection, the medium was replaced by HBSS. Coelenterazine $\mathrm{H}$ was added at $5 \mu \mathrm{M}$, after a 5-min incubation cells were stimulated with increasing concentrations of ghrelin. Readings was performed in a Mithras LB 940 microplate reader which allows sequential integration of the luminescence signal with $485 \mathrm{~nm}$ filter for luciferase emission and $530 \mathrm{~nm}$ filter for YFP emission. Net BRET values were calculated by subtraction of BRET ratios obtained in cells transfected with rLuc donor alone and multiplied by 1000 as milli BRET units (mBU).

\section{Confocal Microscopy}

HEK293 cells transiently expressing $\beta$-arrestin 2 -eYFP and either wild-type or Q343X-rGHSR were plated on 35-mm poly-L-lysine-coated glass-bottom culture dishes and cultured overnight. Images of $\beta$-arrestin $2^{-}$ eYFP translocation were acquired from live cells in real time at $37^{\circ} \mathrm{C}$ and $5 \% \mathrm{CO}_{2}$ before and after rat ghrelin treatment (300 nM) using a $488 \mathrm{~nm}$ excitation and a 505-530 $\mathrm{nm}$ band pass emission. Confocal microscopy was performed on a Leica SP5 confocal microscope. 


\section{Animals}

The mutant line of FHH-Ghsr ${ }^{\mathrm{mlMcwi}}$ rats carrying the $G h s r^{\mathrm{Q} 343 \mathrm{X}}$ allele was obtained from the Medical College of Wisconsin (Milwaukee, WI, USA). It was developed as part of the PhysGen Program (http://pga.mcw.edu) on the inbred fawn hooded hypertensive (FHH) rat genetic background. To remove any residual background mutations due to the ENU treatment elsewhere in the genome, the Ghsr heterozygous rats were crossed against parental animals of the same FHH strain for at least four generations. The homozygous FHH-Ghsr ${ }^{\mathrm{m} 1 \mathrm{Mcwi}}$ rats and wild-type littermates are referred to as $G h s r^{\mathrm{M} / \mathrm{M}}$ and $G h s r^{\mathrm{WT} / \mathrm{WT}}$ rats, respectively. Animals used in this study were group housed (4 per cage) unless otherwise specified, in a room with controlled temperature $\left(22-24^{\circ} \mathrm{C}\right)$ and illumination $(12 \mathrm{~h}$ light/dark schedule with lights on at 7:00 a.m.). Animals had free access to water and chow diet (A04, SAFE). The genotype of the rats at the Ghsr locus was performed according to a PCR RFLP procedure as previously describe (33).

\section{Food intake experiments}

Rats were habituated to single housing for at least 1week before the beginning of the experiment. Basal food consumption was determined by averaging daily food consumption during 6 days. In agonistinduced food intake experiment, individually housed animals were habituated to subcutaneous saline injections for two days to minimize stress. Experiments were repeated in a crossover-designed manner so that animals were randomly assigned to receive saline or hexarelin injection (0.04 to $722 \mathrm{nmol} / \mathrm{kg}$, Sigma) every two days. Food intake was monitored for $4 \mathrm{~h}$ after the injection at 10:00 a.m.

\section{Growth hormone secretion assay}

Two days before blood sampling, an indwelling cannula (Solomon Instech, Plymouth Meeting, PA USA) was inserted into the right atrium in 10 month-old male rats under isoflurane anesthesia. The other end of the cannula was connected to a vascular access harness (Solomon Instech, Plymouth Meeting, PA USA) and filled with a glycerol/heparin catheter lock solution $(500 \mathrm{IU} / \mathrm{ml})$. One hour before the sampling 
period, the distal end of the cannula was connected to a polyethylene catheter filled with $25 \mathrm{IU} / \mathrm{ml}$ heparinized saline. After sampling, red blood cells were resuspended in a $25 \mathrm{IU} / \mathrm{ml}$ heparinized saline solution and re-injected at the end of the blood sampling period to attenuate hemodynamic modifications. Ghrelin (0.5 to $10.0 \mu \mathrm{g} / \mathrm{rat})$ was administered i.v. at 10:00 a.m. $\left(\mathrm{t}_{0}\right)$ and blood samples withdrawn before injection ( $\mathrm{t}_{-20}$ and $\left.\mathrm{t}_{0} \mathrm{~min}\right)$ and after injection $\left(\mathrm{t}_{5}, \mathrm{t}_{10}, \mathrm{t}_{20}, \mathrm{t}_{30}, \mathrm{t}_{40}, \mathrm{t}_{50}\right.$ and $\left.\mathrm{t}_{60} \mathrm{~min}\right)$ for $\mathrm{GH}$ determination.

\section{Glucose tolerance test}

Cannulated male rats that had been fasted for 16 hours received a glucose load by oral gavage $(2.5 \mathrm{~g} / \mathrm{kg})$. Iterative blood samples were collected before $\left(t_{0}\right)$ and after the glucose load at time points $t_{10}, t_{20}, t_{40}, t_{60}$ and $\mathrm{t}_{120}$ min for blood glucose and plasma insulin determinations.

\section{Caloric restriction}

Ad libitum-fed male rats in grouped cages were subjected to a 16-day caloric restriction before refeeding at day 17. Rats underwent daily body weight, blood glucose measurements and blood sampling for growth hormone and ghrelin measurements by tail bleeding. Blood sampling occurred 30 min before rats were given free access to chow diet for one hour (at 4:30 p.m.), to achieve on average a $70 \%$ caloric restriction.

\section{Blood glucose and hormone measurements}

Blood sampling in living animals was performed through an indwelling cannula or from the tail. Blood samples for GH or insulin were collected on EDTA $(20 \mathrm{mg} / \mathrm{ml})$, centrifuged and plasma were stored at $-20^{\circ} \mathrm{C}$ until measurements. As for ghrelin measurements, blood samples pre-treated with the protease inhibitor p-hydroxymercuribenzoate (PHMB, $0.4 \mathrm{mM}$ final). After centrifugation, plasma was acidified with $\mathrm{HCl}(0.1 \mathrm{M}$ final $)$ and stored at $-80^{\circ} \mathrm{C}$. Plasma $\mathrm{GH}$ concentrations were determined by a double antibody EIA assay using materials supplied by the National Hormone and Peptide Program (NHPP) as 
previously described (49). Insulin concentrations were determined by ELISA (Mercodia) and rat acyl ghrelin and des-acyl ghrelin concentrations were measured with ELISA kits (Bertin Pharma).

\section{Statistics}

Results are presented as mean \pm SEM. Sample size (n) and $P$ values are given in the figure legends. Statistical analyses and curve fitting were performed using R software and GraphPad Prism® 5.01, respectively. Differences between 2 groups were determined using Mann-Whitney test. Comparisons of multiple groups were performed using two-way ANOVA, repeated measures ANOVA or ANOVA on aligned rank transformed data (ARTool package). For all statistical analyses, a $P$ value of less than 0.05 was considered as significant.

\section{Study approval}

The procedures involving rats were approved by the ethics committee on animal experimentation of the Université Paris Descartes (agreement no. CEEA34.JP.055.12). 


\section{$\underline{\text { References and Notes }}$}

1. M. Kojima, H. Hosoda, Y. Date, M. Nakazato, H. Matsuo, K. Kangawa, Ghrelin is a growthhormone-releasing acylated peptide from stomach. Nature 402, 656-660 (1999).

2. A. M. Naleid, M. K. Grace, D. E. Cummings, A. S. Levine, Ghrelin induces feeding in the mesolimbic reward pathway between the ventral tegmental area and the nucleus accumbens. Peptides 26, 2274-2279 (2005).

3. A. Abizaid, Z. W. Liu, Z. B. Andrews, M. Shanabrough, E. Borok, J. D. Elsworth, R. H. Roth, M. W. Sleeman, M. R. Picciotto, M. H. Tschop, X. B. Gao, T. L. Horvath, Ghrelin modulates the activity and synaptic input organization of midbrain dopamine neurons while promoting appetite. J Clin Invest 116, 3229-3239 (2006).

4. E. Jerlhag, E. Egecioglu, S. L. Dickson, A. Douhan, L. Svensson, J. A. Engel, Ghrelin administration into tegmental areas stimulates locomotor activity and increases extracellular concentration of dopamine in the nucleus accumbens. Addict Biol 12, 6-16 (2007).

5. M. Tschop, D. L. Smiley, M. L. Heiman, Ghrelin induces adiposity in rodents. Nature 407, 908$913(2000)$.

6. M. Nakazato, N. Murakami, Y. Date, M. Kojima, H. Matsuo, K. Kangawa, S. Matsukura, A role for ghrelin in the central regulation of feeding. Nature 409, 194-198 (2001).

7. H. Y. Chen, M. E. Trumbauer, A. S. Chen, D. T. Weingarth, J. R. Adams, E. G. Frazier, Z. Shen, D. J. Marsh, S. D. Feighner, X. M. Guan, Z. Ye, R. P. Nargund, R. G. Smith, L. H. Van der Ploeg, A. D. Howard, D. J. MacNeil, S. Qian, Orexigenic action of peripheral ghrelin is mediated by neuropeptide Y and agouti-related protein. Endocrinology 145, 2607-2612 (2004).

8. C. Theander-Carrillo, P. Wiedmer, P. Cettour-Rose, R. Nogueiras, D. Perez-Tilve, P. Pfluger, T. R. Castaneda, P. Muzzin, A. Schurmann, I. Szanto, M. H. Tschop, F. Rohner-Jeanrenaud, Ghrelin 
action in the brain controls adipocyte metabolism. Journal of Clinical Investigation 116, 19831993 (2006).

9. A. D. Howard, S. D. Feighner, D. F. Cully, J. P. Arena, P. A. Liberator, C. I. Rosenblum, M. Hamelin, D. L. Hreniuk, O. C. Palyha, J. Anderson, P. S. Paress, C. Diaz, M. Chou, K. K. Liu, K. K. McKee, S. S. Pong, L. Y. Chaung, A. Elbrecht, M. Dashkevicz, R. Heavens, M. Rigby, D. J. Sirinathsinghji, D. C. Dean, D. G. Melillo, L. H. Van der Ploeg, et al., A receptor in pituitary and hypothalamus that functions in growth hormone release. Science 273, 974-977 (1996).

10. Y. Sun, P. Wang, H. Zheng, R. G. Smith, Ghrelin stimulation of growth hormone release and appetite is mediated through the growth hormone secretagogue receptor. Proc Natl Acad Sci U S A 101, 4679-4684 (2004).

11. X. M. Guan, H. Yu, O. C. Palyha, K. K. McKee, S. D. Feighner, D. J. Sirinathsinghji, R. G. Smith, L. H. Van der Ploeg, A. D. Howard, Distribution of mRNA encoding the growth hormone secretagogue receptor in brain and peripheral tissues. Brain Res Mol Brain Res 48, 23-29 (1997).

12. B. Holst, A. Cygankiewicz, T. H. Jensen, M. Ankersen, T. W. Schwartz, High constitutive signaling of the ghrelin receptor--identification of a potent inverse agonist. Mol Endocrinol 17, 2201-2210 (2003).

13. D. Mousseaux, L. Le Gallic, J. Ryan, C. Oiry, D. Gagne, J. A. Fehrentz, J. C. Galleyrand, J. Martinez, Regulation of ERK1/2 activity by ghrelin-activated growth hormone secretagogue receptor 1A involves a PLC/PKCvarepsilon pathway. Br J Pharmacol 148, 350-365 (2006).

14. K. Dezaki, M. Kakei, T. Yada, Ghrelin uses Galphai2 and activates voltage-dependent K+ channels to attenuate glucose-induced $\mathrm{Ca} 2+$ signaling and insulin release in islet beta-cells: novel signal transduction of ghrelin. Diabetes 56, 2319-2327 (2007).

15. M. Damian, J. Marie, J. P. Leyris, J. A. Fehrentz, P. Verdie, J. Martinez, J. L. Baneres, S. Mary, High constitutive activity is an intrinsic feature of ghrelin receptor protein: a study with a 
functional monomeric GHS-R1a receptor reconstituted in lipid discs. J Biol Chem 287, 36303641 (2012).

16. A. Kern, M. Mavrikaki, C. Ullrich, R. Albarran-Zeckler, A. F. Brantley, R. G. Smith, Hippocampal Dopamine/DRD1 Signaling Dependent on the Ghrelin Receptor. Cell 163, 11761190 (2015).

17. A. Kern, R. Albarran-Zeckler, H. E. Walsh, R. G. Smith, Apo-ghrelin receptor forms heteromers with DRD2 in hypothalamic neurons and is essential for anorexigenic effects of DRD2 agonism. Neuron 73, 317-332 (2012).

18. N. D. Holliday, B. Holst, E. A. Rodionova, T. W. Schwartz, H. M. Cox, Importance of constitutive activity and arrestin independent mechanisms for intracellular trafficking of the ghrelin receptor. Molecular Endocrinology 21, 3100-3112 (2007).

19. T. Evron, S. M. Peterson, N. M. Urs, Y. Bai, L. K. Rochelle, M. G. Caron, L. S. Barak, G Protein and beta-arrestin signaling bias at the ghrelin receptor. J Biol Chem 289, 33442-33455 (2014).

20. B. Sivertsen, N. Holliday, A. N. Madsen, B. Holst, Functionally biased signalling properties of 7TM receptors - opportunities for drug development for the ghrelin receptor. Br J Pharmacol $170,1349-1362$ (2013).

21. T. D. Muller, R. Nogueiras, M. L. Andermann, Z. B. Andrews, S. D. Anker, J. Argente, R. L. Batterham, S. C. Benoit, C. Y. Bowers, F. Broglio, F. F. Casanueva, D. D'Alessio, I. Depoortere, A. Geliebter, E. Ghigo, P. A. Cole, M. Cowley, D. E. Cummings, A. Dagher, S. Diano, S. L. Dickson, C. Dieguez, R. Granata, H. J. Grill, K. Grove, K. M. Habegger, K. Heppner, M. L. Heiman, L. Holsen, B. Holst, A. Inui, J. O. Jansson, H. Kirchner, M. Korbonits, B. Laferrere, C. W. LeRoux, M. Lopez, S. Morin, M. Nakazato, R. Nass, D. Perez-Tilve, P. T. Pfluger, T. W. Schwartz, R. J. Seeley, M. Sleeman, Y. Sun, L. Sussel, J. Tong, M. O. Thorner, A. J. van der 
Lely, L. H. van der Ploeg, J. M. Zigman, M. Kojima, K. Kangawa, R. G. Smith, T. Horvath, M. H. Tschop, Ghrelin. Mol Metab 4, 437-460 (2015).

22. J. Pantel, M. Legendre, S. Cabrol, L. Hilal, Y. Hajaji, S. Morisset, S. Nivot, M. P. Vie-Luton, D. Grouselle, M. de Kerdanet, A. Kadiri, J. Epelbaum, Y. Le Bouc, S. Amselem, Loss of constitutive activity of the growth hormone secretagogue receptor in familial short stature. J Clin Invest 116, 760-768 (2006).

23. H. Lango Allen, K. Estrada, G. Lettre, S. I. Berndt, M. N. Weedon, F. Rivadeneira, C. J. Willer, A. U. Jackson, S. Vedantam, S. Raychaudhuri, T. Ferreira, A. R. Wood, R. J. Weyant, A. V. Segre, E. K. Speliotes, E. Wheeler, N. Soranzo, J. H. Park, J. Yang, D. Gudbjartsson, N. L. Heard-Costa, J. C. Randall, L. Qi, A. Vernon Smith, R. Magi, T. Pastinen, L. Liang, I. M. Heid, J. Luan, G. Thorleifsson, T. W. Winkler, M. E. Goddard, K. Sin Lo, C. Palmer, T. Workalemahu, Y. S. Aulchenko, A. Johansson, M. C. Zillikens, M. F. Feitosa, T. Esko, T. Johnson, S. Ketkar, P. Kraft, M. Mangino, I. Prokopenko, D. Absher, E. Albrecht, F. Ernst, N. L. Glazer, C. Hayward, J. J. Hottenga, K. B. Jacobs, J. W. Knowles, Z. Kutalik, K. L. Monda, O. Polasek, M. Preuss, N. W. Rayner, N. R. Robertson, V. Steinthorsdottir, J. P. Tyrer, B. F. Voight, F. Wiklund, J. Xu, J. H. Zhao, D. R. Nyholt, N. Pellikka, M. Perola, J. R. Perry, I. Surakka, M. L. Tammesoo, E. L. Altmaier, N. Amin, T. Aspelund, T. Bhangale, G. Boucher, D. I. Chasman, C. Chen, L. Coin, M. N. Cooper, A. L. Dixon, Q. Gibson, E. Grundberg, K. Hao, M. Juhani Junttila, L. M. Kaplan, J. Kettunen, I. R. Konig, T. Kwan, R. W. Lawrence, D. F. Levinson, M. Lorentzon, B. McKnight, A. P. Morris, M. Muller, J. Suh Ngwa, S. Purcell, S. Rafelt, R. M. Salem, E. Salvi, S. Sanna, J. Shi, U. Sovio, J. R. Thompson, M. C. Turchin, L. Vandenput, D. J. Verlaan, V. Vitart, C. C. White, A. Ziegler, P. Almgren, A. J. Balmforth, H. Campbell, L. Citterio, A. De Grandi, A. Dominiczak, J. Duan, P. Elliott, R. Elosua, J. G. Eriksson, N. B. Freimer, E. J. Geus, N. Glorioso, S. Haiqing, A. L. Hartikainen, A. S. Havulinna, A. A. Hicks, J. Hui, W. Igl, T. Illig, A. Jula, E. Kajantie, T. O. Kilpelainen, M. Koiranen, I. Kolcic, S. Koskinen, P. Kovacs, J. Laitinen, J. Liu, 
M. L. Lokki, A. Marusic, A. Maschio, T. Meitinger, A. Mulas, G. Pare, A. N. Parker, J. F. Peden, A. Petersmann, I. Pichler, K. H. Pietilainen, A. Pouta, M. Ridderstrale, J. I. Rotter, J. G. Sambrook, A. R. Sanders, C. O. Schmidt, J. Sinisalo, J. H. Smit, H. M. Stringham, G. Bragi Walters, E. Widen, S. H. Wild, G. Willemsen, L. Zagato, L. Zgaga, P. Zitting, H. Alavere, M. Farrall, W. L. McArdle, M. Nelis, M. J. Peters, S. Ripatti, J. B. van Meurs, K. K. Aben, K. G. Ardlie, J. S. Beckmann, J. P. Beilby, R. N. Bergman, S. Bergmann, F. S. Collins, D. Cusi, M. den Heijer, G. Eiriksdottir, P. V. Gejman, A. S. Hall, A. Hamsten, H. V. Huikuri, C. Iribarren, M. Kahonen, J. Kaprio, S. Kathiresan, L. Kiemeney, T. Kocher, L. J. Launer, T. Lehtimaki, O. Melander, T. H. Mosley, Jr., A. W. Musk, M. S. Nieminen, C. J. O'Donnell, C. Ohlsson, B. Oostra, L. J. Palmer, O. Raitakari, P. M. Ridker, J. D. Rioux, A. Rissanen, C. Rivolta, H. Schunkert, A. R. Shuldiner, D. S. Siscovick, M. Stumvoll, A. Tonjes, J. Tuomilehto, G. J. van Ommen, J. Viikari, A. C. Heath, N. G. Martin, G. W. Montgomery, M. A. Province, M. Kayser, A. M. Arnold, L. D. Atwood, E. Boerwinkle, S. J. Chanock, P. Deloukas, C. Gieger, H. Gronberg, P. Hall, A. T. Hattersley, C. Hengstenberg, W. Hoffman, G. M. Lathrop, V. Salomaa, S. Schreiber, M. Uda, D. Waterworth, A. F. Wright, T. L. Assimes, I. Barroso, A. Hofman, K. L. Mohlke, D. I. Boomsma, M. J. Caulfield, L. A. Cupples, J. Erdmann, C. S. Fox, V. Gudnason, U. Gyllensten, T. B. Harris, R. B. Hayes, M. R. Jarvelin, V. Mooser, P. B. Munroe, W. H. Ouwehand, B. W. Penninx, P. P. Pramstaller, T. Quertermous, I. Rudan, N. J. Samani, T. D. Spector, H. Volzke, H. Watkins, J. F. Wilson, L. C. Groop, T. Haritunians, F. B. Hu, R. C. Kaplan, A. Metspalu, K. E. North, D. Schlessinger, N. J. Wareham, D. J. Hunter, J. R. O'Connell, D. P. Strachan, H. E. Wichmann, I. B. Borecki, C. M. van Duijn, E. E. Schadt, U.

Thorsteinsdottir, L. Peltonen, A. G. Uitterlinden, P. M. Visscher, N. Chatterjee, R. J. Loos, M. Boehnke, M. I. McCarthy, E. Ingelsson, C. M. Lindgren, G. R. Abecasis, K. Stefansson, T. M. Frayling, J. N. Hirschhorn, Hundreds of variants clustered in genomic loci and biological pathways affect human height. Nature 467, 832-838 (2010). 
24. M. B. Lanktree, Y. Guo, M. Murtaza, J. T. Glessner, S. D. Bailey, N. C. Onland-Moret, G. Lettre, H. Ongen, R. Rajagopalan, T. Johnson, H. Shen, C. P. Nelson, N. Klopp, J. Baumert, S. Padmanabhan, N. Pankratz, J. S. Pankow, S. Shah, K. Taylor, J. Barnard, B. J. Peters, C. M. Maloney, M. T. Lobmeyer, A. Stanton, M. H. Zafarmand, S. P. Romaine, A. Mehta, E. P. van Iperen, Y. Gong, T. S. Price, E. N. Smith, C. E. Kim, Y. R. Li, F. W. Asselbergs, L. D. Atwood, K. M. Bailey, D. Bhatt, F. Bauer, E. R. Behr, T. Bhangale, J. M. Boer, B. O. Boehm, J. P. Bradfield, M. Brown, P. S. Braund, P. R. Burton, C. Carty, H. R. Chandrupatla, W. Chen, J. Connell, C. Dalgeorgou, A. Boer, F. Drenos, C. C. Elbers, J. C. Fang, C. S. Fox, E. C. Frackelton, B. Fuchs, C. E. Furlong, Q. Gibson, C. Gieger, A. Goel, D. E. Grobbee, C. Hastie, P. J. Howard, G. H. Huang, W. C. Johnson, Q. Li, M. E. Kleber, B. E. Klein, R. Klein, C. Kooperberg, B. Ky, A. Lacroix, P. Lanken, M. Lathrop, M. Li, V. Marshall, O. Melander, F. D. Mentch, N. J. Meyer, K. L. Monda, A. Montpetit, G. Murugesan, K. Nakayama, D. Nondahl, A. Onipinla, S. Rafelt, S. J. Newhouse, F. G. Otieno, S. R. Patel, M. E. Putt, S. Rodriguez, R. N. Safa, D. B. Sawyer, P. J. Schreiner, C. Simpson, S. Sivapalaratnam, S. R. Srinivasan, C. Suver, G. Swergold, N. K. Sweitzer, K. A. Thomas, B. Thorand, N. J. Timpson, S. Tischfield, M. Tobin, M. Tomaszweski, W. M. Verschuren, C. Wallace, B. Winkelmann, H. Zhang, D. Zheng, L. Zhang, J. M. Zmuda, R. Clarke, A. J. Balmforth, J. Danesh, I. N. Day, N. J. Schork, P. I. de Bakker, C. Delles, D. Duggan, A. D. Hingorani, J. N. Hirschhorn, M. H. Hofker, S. E. Humphries, M. Kivimaki, D. A. Lawlor, K. Kottke-Marchant, J. L. Mega, B. D. Mitchell, D. A. Morrow, J. Palmen, S. Redline, D. C. Shields, A. R. Shuldiner, P. M. Sleiman, G. D. Smith, M. Farrall, Y. Jamshidi, D. C. Christiani, J. P. Casas, A. S. Hall, P. A. Doevendans, J. D. Christie, G. S. Berenson, S. S. Murray, T. Illig, G. W. Dorn, 2nd, T. P. Cappola, E. Boerwinkle, P. Sever, D. J. Rader, M. P. Reilly, M. Caulfield, P. J. Talmud, E. Topol, J. C. Engert, K. Wang, A. Dominiczak, A. Hamsten, S. P. Curtis, R. L. Silverstein, L. A. Lange, M. S. Sabatine, M. Trip, D. Saleheen, J. F. Peden, K. J. Cruickshanks, W. Marz, J. R. O'Connell, O. H. Klungel, C. Wijmenga, A. H. Maitland-van der Zee, E. E. Schadt, J. A. Johnson, G. P. Jarvik, G. J. Papanicolaou, S. F. Grant, P. B. Munroe, K. E. North, N. 
J. Samani, W. Koenig, T. R. Gaunt, S. S. Anand, Y. T. van der Schouw, N. Soranzo, G. A. Fitzgerald, A. Reiner, R. A. Hegele, H. Hakonarson, B. J. Keating, Meta-analysis of Dense Genecentric Association Studies Reveals Common and Uncommon Variants Associated with Height. Am J Hum Genet 88, 6-18 (2011).

25. S. Riedl, I. Hughes, M. Harris, G. M. Leong, J. Beilby, P. Sly, C. S. Choong, GH secretagogue receptor gene polymorphisms are associated with stature throughout childhood. Eur J Endocrinol $166,1079-1085$ (2012).

26. B. Liu, E. A. Garcia, M. Korbonits, Genetic studies on the ghrelin, growth hormone secretagogue receptor (GHSR) and ghrelin O-acyl transferase (GOAT) genes. Peptides 32, 2191-2207 (2011).

27. E. Karra, O. G. O'Daly, A. I. Choudhury, A. Yousseif, S. Millership, M. T. Neary, W. R. Scott, K. Chandarana, S. Manning, M. E. Hess, H. Iwakura, T. Akamizu, Q. Millet, C. Gelegen, M. E. Drew, S. Rahman, J. J. Emmanuel, S. C. Williams, U. U. Ruther, J. C. Bruning, D. J. Withers, F. O. Zelaya, R. L. Batterham, A link between FTO, ghrelin, and impaired brain food-cue responsivity. J Clin Invest 123, 3539-3551 (2013).

28. E. Egecioglu, E. Jerlhag, N. Salome, K. P. Skibicka, D. Haage, Y. M. Bohlooly, D. Andersson, M. Bjursell, D. Perrissoud, J. A. Engel, S. L. Dickson, Ghrelin increases intake of rewarding food in rodents. Addict Biol 15, 304-311 (2010).

29. M. Perello, I. Sakata, S. Birnbaum, J. C. Chuang, S. Osborne-Lawrence, S. A. Rovinsky, J. Woloszyn, M. Yanagisawa, M. Lutter, J. M. Zigman, Ghrelin increases the rewarding value of high-fat diet in an orexin-dependent manner. Biol Psychiatry 67, 880-886 (2010).

30. J. M. Zigman, Y. Nakano, R. Coppari, N. Balthasar, J. N. Marcus, C. E. Lee, J. E. Jones, A. E. Deysher, A. R. Waxman, R. D. White, T. D. Williams, J. L. Lachey, R. J. Seeley, B. B. Lowell, J. K. Elmquist, Mice lacking ghrelin receptors resist the development of diet-induced obesity. Journal of Clinical Investigation 115, 3564-3572 (2005). 
31. Y. X. Sun, N. F. Butte, J. M. Garcia, R. G. Smith, Characterization of adult ghrelin and ghrelin receptor knockout mice under positive and negative energy balance. Endocrinology 149, 843-850 (2008).

32. P. T. Pfluger, H. Kirchner, S. Gunnel, B. Schrott, D. Perez-Tilve, S. Fu, S. C. Benoit, T. Horvath, H. G. Joost, K. E. Wortley, M. W. Sleeman, M. H. Tschop, Simultaneous deletion of ghrelin and its receptor increases motor activity and energy expenditure. Am J Physiol Gastrointest Liver Physiol 294, G610-618 (2008).

33. M. Bulbul, R. Babygirija, J. Zheng, K. Ludwig, H. Xu, J. Lazar, T. Takahashi, Food intake and interdigestive gastrointestinal motility in ghrelin receptor mutant rats. J Gastroenterol 46, 469478 (2011).

34. B. Holst, N. D. Holliday, A. Bach, C. E. Elling, H. M. Cox, T. W. Schwartz, Common structural basis for constitutive activity of the ghrelin receptor family. J Biol Chem 279, 53806-53817 (2004).

35. G. S. Tannenbaum, J. Epelbaum, C. Y. Bowers, Interrelationship between the novel peptide ghrelin and somatostatin/growth hormone-releasing hormone in regulation of pulsatile growth hormone secretion. Endocrinology 144, 967-974 (2003).

36. V. Tolle, P. Zizzari, C. Tomasetto, M. C. Rio, J. Epelbaum, M. T. Bluet-Pajot, In vivo and in vitro effects of ghrelin/motilin-related peptide on growth hormone secretion in the rat. Neuroendocrinology 73, 54-61 (2001).

37. L. Lin, P. K. Saha, X. Ma, I. O. Henshaw, L. Shao, B. H. Chang, E. D. Buras, Q. Tong, L. Chan, O. P. McGuinness, Y. Sun, Ablation of ghrelin receptor reduces adiposity and improves insulin sensitivity during aging by regulating fat metabolism in white and brown adipose tissues. Aging Cell 10, 996-1010 (2011). 
38. S. K. Shenoy, R. J. Lefkowitz, beta-Arrestin-mediated receptor trafficking and signal transduction. Trends Pharmacol Sci 32, 521-533 (2011).

39. A. K. Shukla, K. Xiao, R. J. Lefkowitz, Emerging paradigms of beta-arrestin-dependent seven transmembrane receptor signaling. Trends Biochem Sci 36, 457-469 (2011).

40. K. Balabanian, E. Brotin, V. Biajoux, L. Bouchet-Delbos, E. Lainey, O. Fenneteau, D. Bonnet, L. Fiette, D. Emilie, F. Bachelerie, Proper desensitization of CXCR4 is required for lymphocyte development and peripheral compartmentalization in mice. Blood 119, 5722-5730 (2012).

41. D. J. Morgan, B. J. Davis, C. S. Kearn, D. Marcus, A. J. Cook, J. Wager-Miller, A. Straiker, M. H. Myoga, J. Karduck, E. Leishman, L. J. Sim-Selley, T. A. Czyzyk, H. B. Bradshaw, D. E. Selley, K. Mackie, Mutation of putative GRK phosphorylation sites in the cannabinoid receptor 1 (CB1R) confers resistance to cannabinoid tolerance and hypersensitivity to cannabinoids in mice. J Neurosci 34, 5152-5163 (2014).

42. A. Uchida, J. M. Zigman, M. Perello, Ghrelin and eating behavior: evidence and insights from genetically-modified mouse models. Front Neurosci 7, 121 (2013).

43. M. R. McFarlane, M. S. Brown, J. L. Goldstein, T. J. Zhao, Induced ablation of ghrelin cells in adult mice does not decrease food intake, body weight, or response to high-fat diet. Cell Metab 20, 54-60 (2014).

44. Y. B. Shrestha, K. Wickwire, S. Giraudo, Effect of reducing hypothalamic ghrelin receptor gene expression on energy balance. Peptides 30, 1336-1341 (2009).

45. J. Pantel, M. Legendre, S. Nivot, S. Morisset, M. P. Vie-Luton, Y. le Bouc, J. Epelbaum, S. Amselem, Recessive isolated growth hormone deficiency and mutations in the ghrelin receptor. $J$ Clin Endocrinol Metab 94, 4334-4341 (2009).

46. H. Inoue, N. Kangawa, A. Kinouchi, Y. Sakamoto, C. Kimura, R. Horikawa, Y. Shigematsu, M. Itakura, T. Ogata, K. Fujieda, Identification and functional analysis of novel human growth 
hormone secretagogue receptor (GHSR) gene mutations in Japanese subjects with short stature. $J$ Clin Endocrinol Metab 96, E373-378 (2011).

47. S. P. Cahill, T. Hatchard, A. Abizaid, M. R. Holahan, An examination of early neural and cognitive alterations in hippocampal-spatial function of ghrelin receptor-deficient rats. Behav Brain Res 264, 105-115 (2014).

48. P. J. Wellman, P. S. Clifford, J. A. Rodriguez, S. Hughes, C. Di Francesco, S. Melotto, M. Tessari, M. Corsi, A. Bifone, A. Gozzi, Brain reinforcement system function is ghrelin dependent: studies in the rat using pharmacological fMRI and intracranial self-stimulation. Addict Biol 17, 908-919 (2012).

49. F. J. Steyn, L. Huang, S. T. Ngo, J. W. Leong, H. Y. Tan, T. Y. Xie, A. F. Parlow, J. D. Veldhuis, M. J. Waters, C. Chen, Development of a method for the determination of pulsatile growth hormone secretion in mice. Endocrinology 152, 3165-3171 (2011).

Acknowledgements: The authors are grateful to the PhysGen program (Medical College of Wisconsin, Milwaukee, WI) for providing the FHH rats, to Chloé Got for animal care, to the Phenobrain platform (Centre de Psychiatrie et Neurosciences, F-75014 Paris), to the Unit "Biologie Fonctionnelle et Adaptative" (Université Paris Diderot-CNRS UMR8251, Sorbonne Paris Cité, F-75205 Paris), to Dr. A. F. Parlow (National Hormone and Peptide Program, Los Angeles, CA) for providing the growth hormone reagents, to Dr. Hans Matthes for kindly providing the $\beta$-arrestin ${ }_{2}$-YFP plasmid, to Pr. Christophe Magnan for helpful discussions, to Dr. Benjamin Renquist for the critical review of the manuscript and to Lucie Léon for guidance with statistical analysis. Funding: This work is supported by INSERM and by a grant of the FRM and Danone Foundation (to J.P.). C.M. is recipient of a fellowship of the Université Sorbonne Paris Cité (USPC). Author contributions: Y.C., C.M., P.Z., M.P., J.E., V.T., S.M.-L., and J.P. 
participated in the design and/or interpretation of the experiments or results. Y.C., C.M., P.Z., K.C., M.P., M.K., D.G., and J.P. participated in the acquisition and/or analysis of data. Y.C., C.M., P.Z., J.E., S.M.L., and J.P. participated in drafting and/or revising the manuscript. Competing interests: the authors declare that they have no competing interests. 


\section{$\underline{\text { Figures }}$}

Fig. 1. The Q343X GHSR mutant has impaired ghrelin-induced internalization and $\beta$-arrestin 2 recruitment. (A) Amino acid alignment of the C-terminal domain in mutant and WT rat GHSR. Ser and Thr amino acids are shaded. (B) Ghrelin-induced internalization of HA-tagged GHSR isoforms across time in HEK293 stable clones expressing similar amounts of WT or mutant GHSR isoforms at the cell surface. This experiment was performed at the indicated times before and after a 5-min ghrelin activation challenge at time 0. GHSR immunoreactivity was normalized to that for vehicle-treated cells for each GHSR isoform. * $P<0.05$ Q343X compared to WT (Mann-Whitney test). Bar=10 $\mu$ m. (C) Ghrelininduced translocation of $\beta$-arrestin 2 -eYFP in HEK293 cells. Confocal microscopy was performed on live, ghrelin-stimulated HEK cells transiently co-expressing $\beta$-arrestin ${ }_{2}$-eYFP and GHSR-WT or GHSRQ343X. Scale bar=10 $\mu \mathrm{m}$. (D) Ghrelin-induced $\beta$-arrestin 2 -eYFP recruitment by GHSR-WT-rLuc or GHSR-Q343-rLuc in a BRET assay. The net BRET signal (mBU) obtained in response to increasing concentrations of rat ghrelin in HEK cells transiently expressing $\beta$-arrestin ${ }_{2}$-eYFP as acceptor with GHSR-WT-rLuc or GHSR-Q343-rLuc constructs as the donor is shown. The eYFP/rLuc ratio (inset) is used as an expression control of eYFP and Rluc plasmids. Data in (B) and (D) are mean \pm SEM of four independent experiments performed in technical quadruplicate. Confocal images in (C) are representative of three independent experiments.

Fig. 2. Functional characterization of the Q343X mutation in rat GHSR. (A-C) Calcium flux experiments were performed in stable HEK cell lines that expressed similar amounts of WT or mutant GHSR isoforms at the cell surface. Concentration-response curves of ghrelin (A). Maximum ghrelin response in cells treated with DMSO control, the PLC inhibitor U73122 or the $\mathrm{G}_{\mathrm{i} / \mathrm{o}}$ inhibitor PTX. Statistical analysis indicates a significant effect of inhibitors $(P<0.001$, ANOVA on aligned rank transformed data) (B). Concentration-response curves for the GHSR agonist hexarelin (C). (D, E) 
Transcriptional activity in serum-starved cells transiently expressing a SRE reporter gene and HA-GHSRWT or HA-GHSR-Q343X. Concentration-response curve of ghrelin (D). Maximum ghrelin response in cells treated with DMSO control, the MAPK inhibitor SL237 or the ROCK inhibitor GSK269962.

Statistical analysis indicates a significant effect of the inhibitors $(P<0.001$, ANOVA on aligned rank transformed data) (E). Data in (A) to (E) are mean \pm SEM of at least three independent experiments, each performed in at least four technical replicates. Nonlinear regression curve fitting was used in (A), (C) and (D) to compare mutant to WT concentration response curves and revealed significant differences in the $\mathrm{EC}_{50} \mathrm{~s}$ in $(\mathrm{A})$ and $(\mathrm{C})(P<0.01, \mathrm{~F}$-test $)$ or in the $\mathrm{E}_{\max }$ in $(\mathrm{A}),(\mathrm{C})$ and $(\mathrm{D})(P<0.01, \mathrm{~F}$-test $) . * * P<0.01$, *** $P<0.001$ DMSO compared to inhibitor, Tukey's post-hoc test.

Fig. 3. $G h s r^{\mathrm{M} / \mathrm{M}}$ rats are more sensitive to exogenous ghrelin or agonist. (A-D) Mean profile of growth hormone secretion in 10 month-old $G h s r^{\mathrm{WT} / \mathrm{WT}}$ or $G h s r^{\mathrm{M} / \mathrm{M}}$ male rats before and after stimulation. Iterative blood sampling over a 140-min period: 20 -min baseline $\left(\mathrm{t}_{-20}\right)$ before the first intravenous ghrelin injection at the indicated dose $\left(\mathrm{t}_{0}\right)$ separated from the second intravenous ghrelin injection by $60 \min \left(\mathrm{t}_{60}\right)$. $(\mathbf{E}, \mathbf{F})$ The 60-min area under the curve (AUC) of growth hormone secretion after the first (E) or the second ghrelin injection (F). Statistical analysis using ANOVA on aligned rank transformed data indicates a significant effect of dose $(P<0.001)$, genotype $(P<0.001)$ and trend for interaction dose $\mathrm{x}$ genotype $(P=$ $0.054)(\mathrm{E})$ and a significant effect of dose $(P<0.01)$, genotype $(P<0.001)$ and interaction dose $\mathrm{x}$ genotype $(P<0.01)(\mathrm{F})$. (G) Cumulative chow intake in 4 month-old female and male rats in response to a maximum dose of the GHSR agonist hexarelin or saline. Analysis by repeated measures ANOVA indicates main effects of treatment $(P<0.001)$ and gender $(P<0.001)$. $(\mathbf{H})$ Dose-response curve for the orexigenic effects of hexarelin in 6 month-old $G h s r^{\mathrm{M} / \mathrm{M}}$ or $G h s r^{\mathrm{WT} / \mathrm{WT}}$ male rats. Analysis by repeated measures ANOVA shows significant main effect of dose $(P<0.001)$ and dose $\mathrm{x}$ genotype interaction $(P$ $<0.01$ ). Sample sizes are included in the figure ( $\mathrm{n}$ indicates the number of rats). Data are mean $\pm \mathrm{SEM}$. 
Fig. 4. Body weight and blood glucose concentrations in $G h s r^{\mathrm{M} / \mathrm{M}}$ rats during chronic caloric restriction and refeeding. (A) 10 month-old male ad libitum fed $G h s r^{\mathrm{M} / \mathrm{M}}$ or $G h s r^{\mathrm{WT} / \mathrm{wT}}$ rats were assessed daily for changes in body weight (upper panel), blood glucose concentrations (middle panel) and plasma growth hormone concentrations (lower panel). Statistical analysis using ANOVA on aligned rank transformed data indicates a significant effect of time $(P<0.001)$, of genotype $(P<0.01)$ and an interaction time $\mathrm{x}$ genotype $(P<0.05)$ (top panel). Repeated measures ANOVA indicate a lack of genotype effect (middle and lower panels). (B) Plasma concentrations of acyl ghrelin (upper panel), desacyl ghrelin (middle panel) and acyl ghrelin ratio (lower panel) at $\mathrm{d}_{0}$ (pre-fasting), $\mathrm{d}_{1}$ (24h fasting), $\mathrm{d}_{16}(16$ days of caloric restriction), and $\mathrm{d}_{17}$ (refeeding). Analysis by two-way ANOVA shows significant main effect of time $(P<0.001)$ and of genotype $(P<0.01)$ (upper panel), and main effect of time $(P<0.001)$ (middle panel). Statistical analysis using ANOVA on aligned rank transformed data indicates only a significant effect of time $(P<0.001)$ (lower panel). Data are mean \pm SEM. $* P<0.05 G h s r^{\mathrm{M} / \mathrm{M}}$ compared to $G h s r^{\mathrm{WT} / \mathrm{WT}}$ rats; Bonferroni's post-hoc test.

Fig. 5. Energy and glucose homeostasis of ad libitum -fed adult $G h s r^{\mathrm{M} / \mathrm{M}}$ rats. $(\mathrm{A}, \mathrm{B})$ Body weight in female and male $G h s r^{\mathrm{M} / \mathrm{M}}$ and $G h s r^{\mathrm{WT} / \mathrm{WT}}$ rats at the indicated ages. Statistical analysis using two-way ANOVA indicates a significant effect of genotype $(P<0.001)$, gender $(P<0.001)$ and an interaction $(P<$ 0.05) only at 3 months. (C) Body weight assessed over time. Repeated measures ANOVA indicates a significant effect of genotype $(P<0.001)$, age $(P<0.001)$ and gender $(P<0.001)$. (D) Nose-to-anus measurements. Two-way ANOVA shows a lack of genotype effect. (E, F) Body composition using quantitative nuclear magnetic resonance at 6 months of age. Statistical analysis using ANOVA on aligned rank transformed data shows a significant effect of genotype $(P<0.05)$ for fat mass only. $(\mathbf{G})$ Plasma leptin concentrations in 9-month old male rats. ** $P<0.01 G h s r^{\mathrm{M} / \mathrm{M}}$ compared to $G h s r^{\mathrm{WT} / \mathrm{WT}}$, MannWhitney test. (H, I) Daily chow intake in adult $G h s r^{\mathrm{M} / \mathrm{M}}$ or $G h s r^{\mathrm{WT} / \mathrm{WT}} 4$ month-old female and male rats. Statistical analysis indicates genotype effect only without adjusting to body weight $(P<0.05$, two-way ANOVA). (J) Homeostasis model assessment of insulin resistance (HOMA-IR). $* P<0.05 G h s r^{\mathrm{M} / \mathrm{M}}$ 
compared to $G h s r^{\mathrm{WT} / \mathrm{WT}}$, Mann-Whitney test. $(\mathbf{K}, \mathbf{L})$ Glucose and insulin responses following dextrose loading in fasted 10-month old male rats. Repeated measures ANOVA indicates a significant genotype effect in blood glucose response only $(P<0.05)$. Sample sizes are included in the figure (n indicates the number of rats). Data are mean \pm SEM.

\section{Fig. 6. The physiological role of GHSR signaling pathways according to the $G h s r^{0343 x}$ rat model.}

Because of the selective blockade of ligand-mediated GHSR internalization and $\beta$-arrestin recruitment, ghrelin binding to the Q343X mutant GHSR enhances G protein signaling. The rats with this mutant receptor show improved GHSR sensitivity to endogenous ghrelin tone, enhanced body weight and adiposity, and decreased glucose tolerance independently of an effect on food intake. 
A

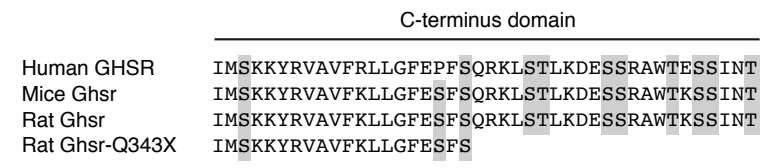

C

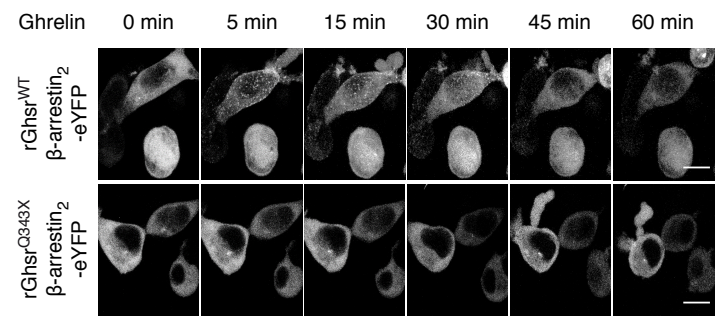

B

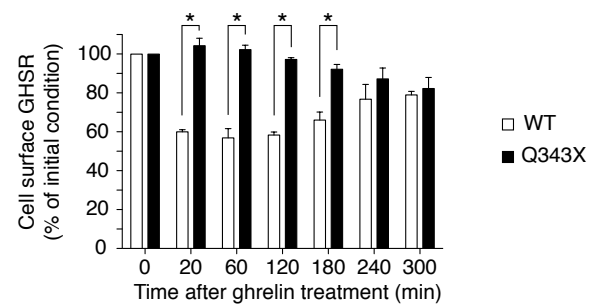

D

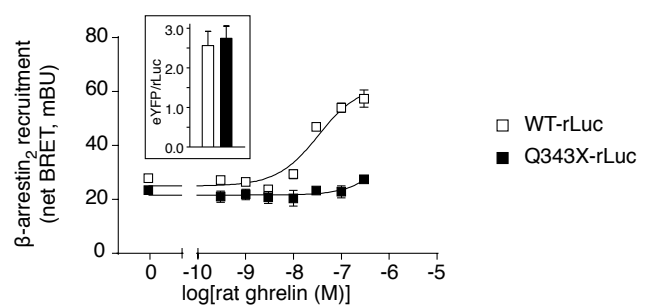

Fig. 1 
A

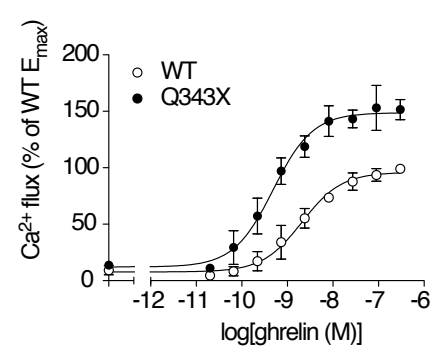

C

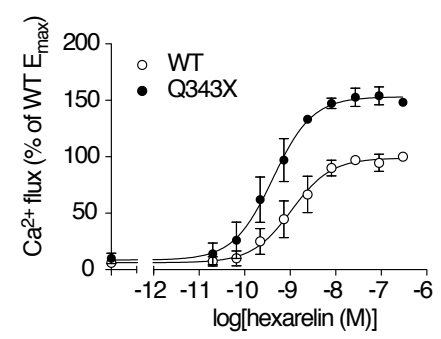

E

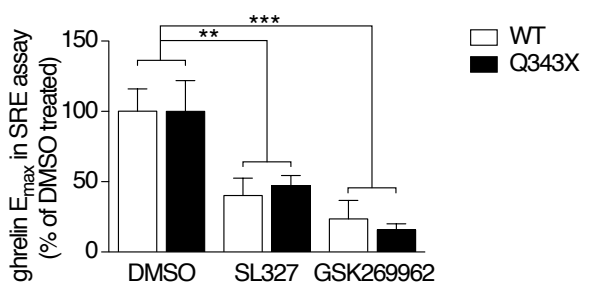

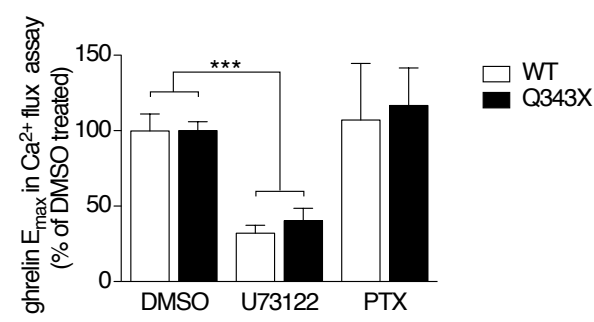

D

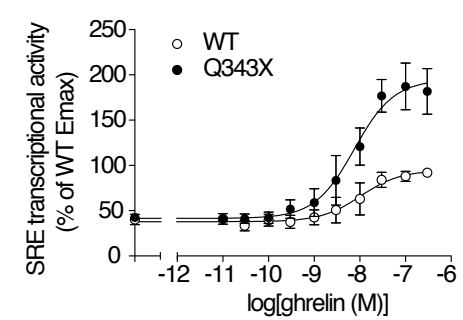

Fig. 2 
A

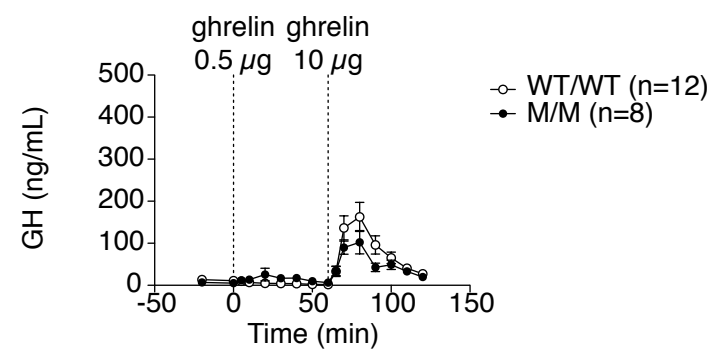

C

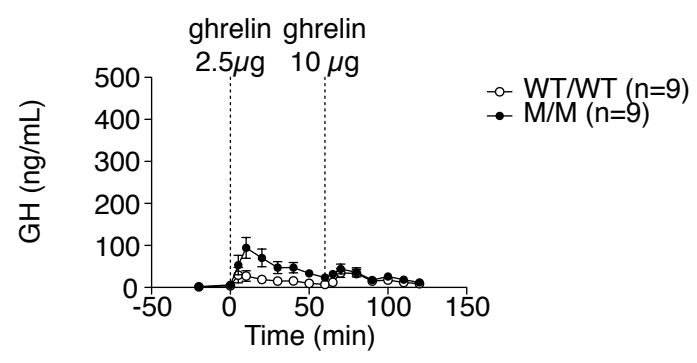

E

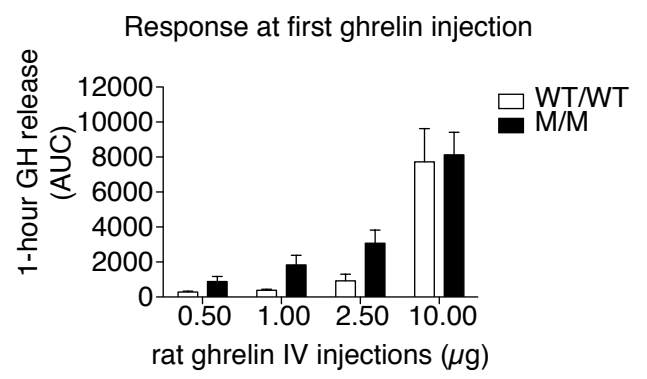

G

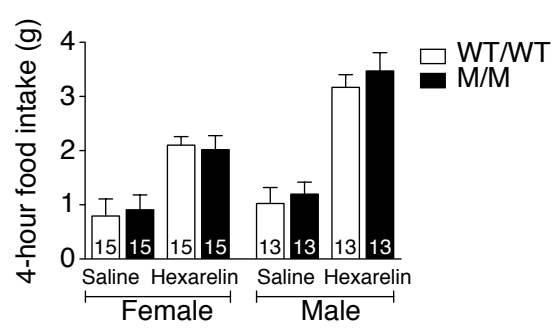

B

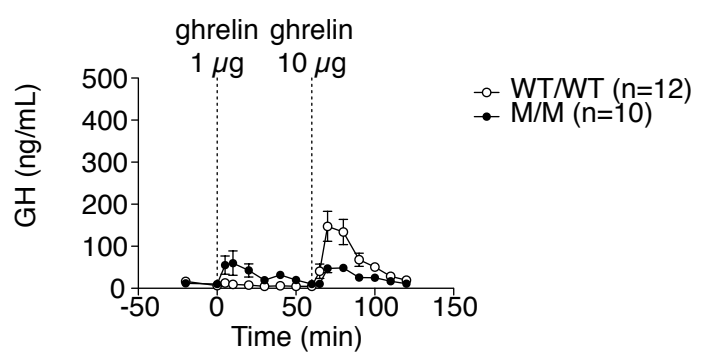

D

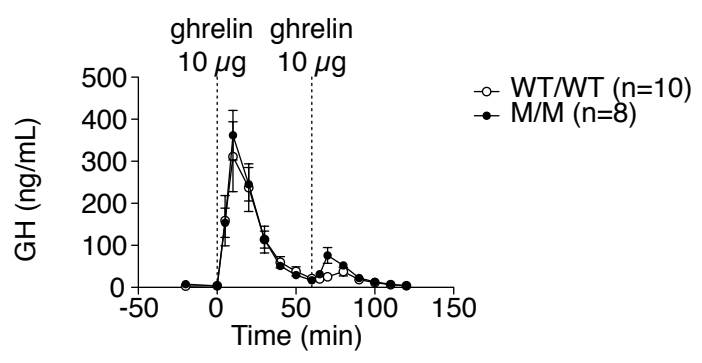

F

Response at second ghrelin injection (10 $\mathrm{gg})$

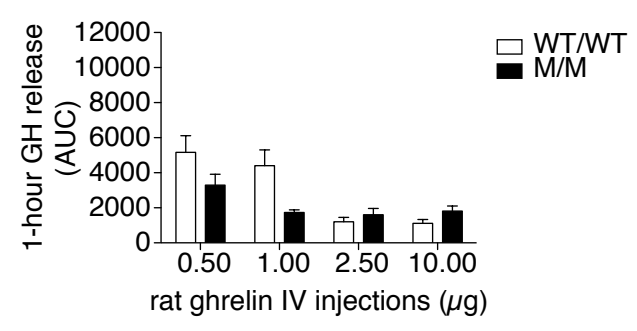

$\mathrm{H}$

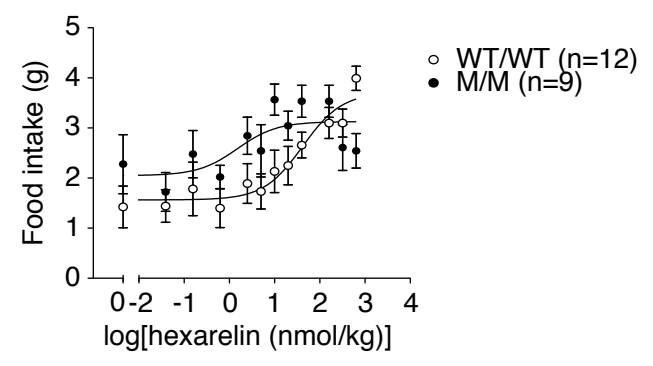

Fig. 3 
A
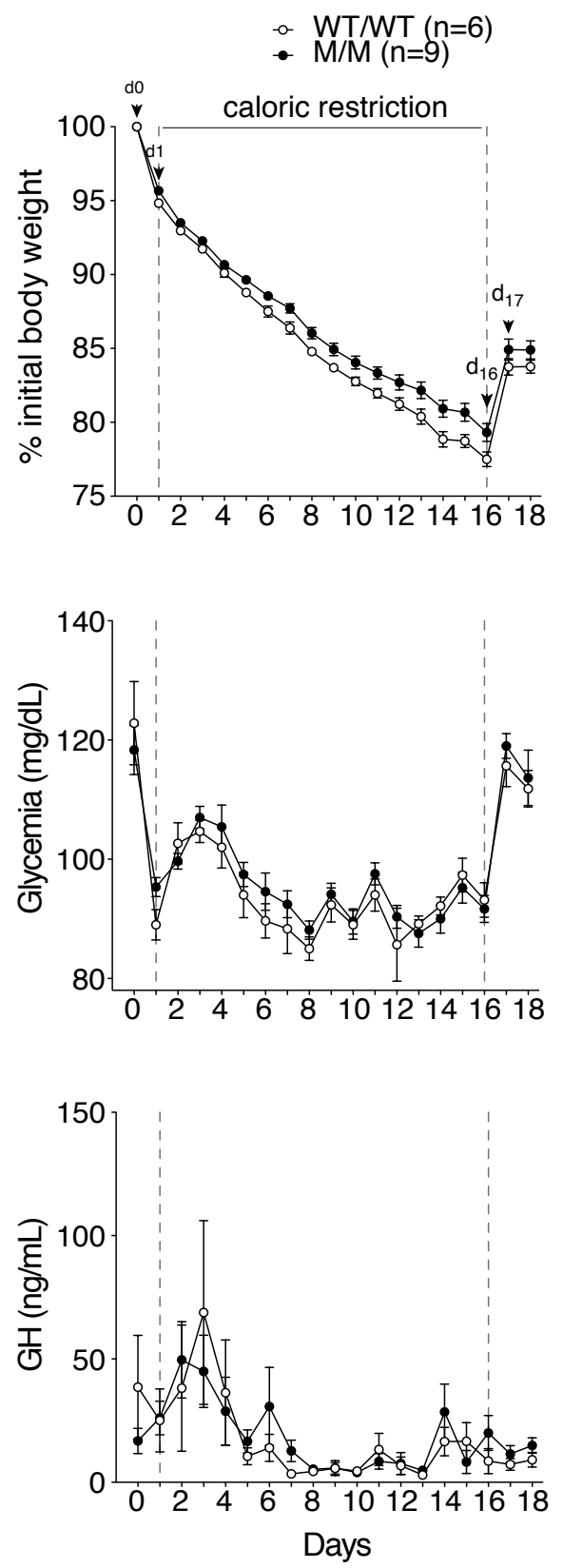

B
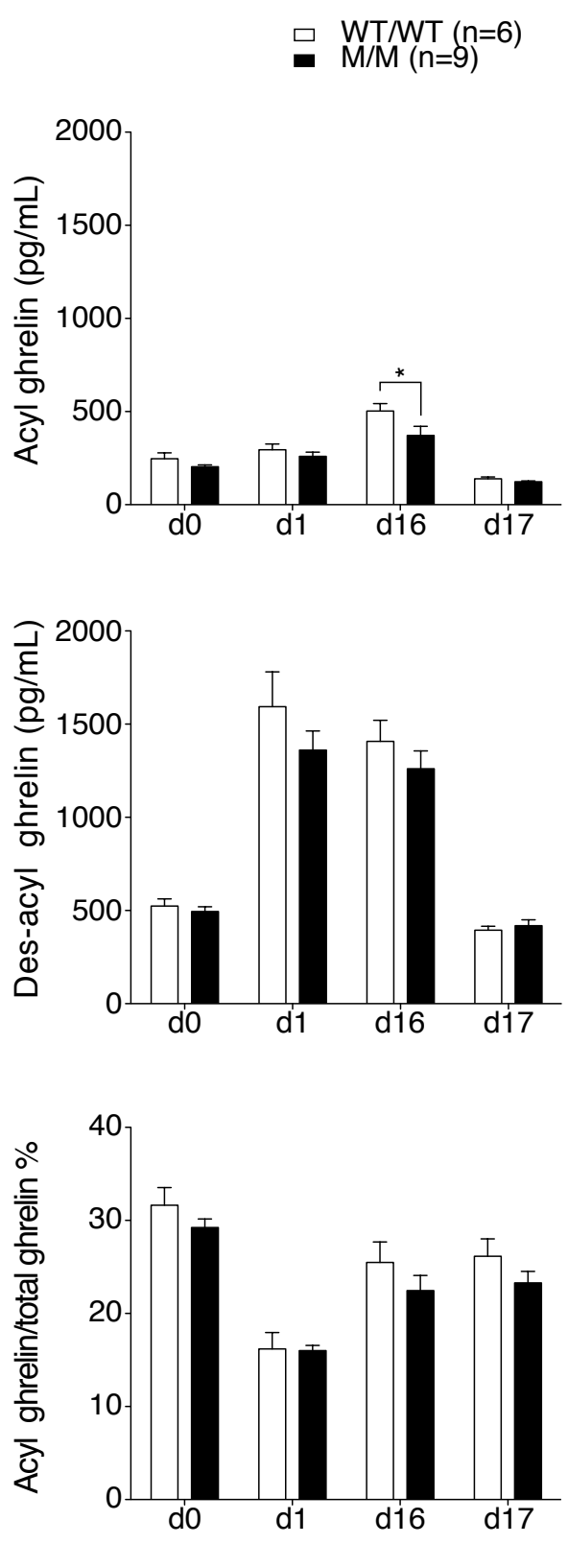

Fig. 4 
A

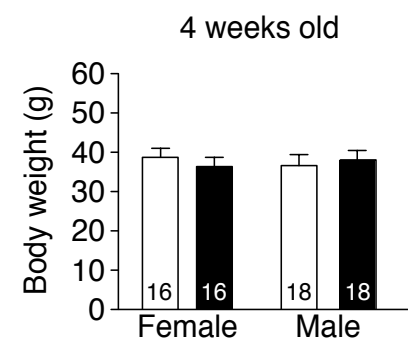

D

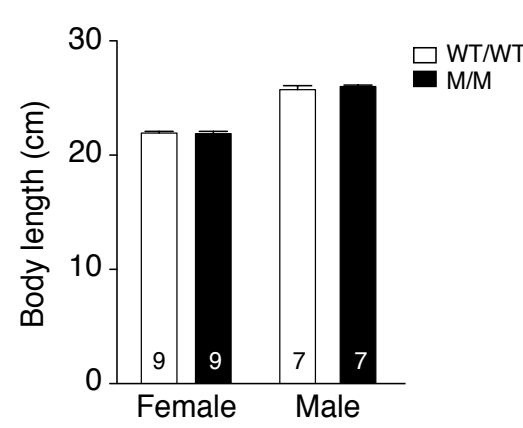

G

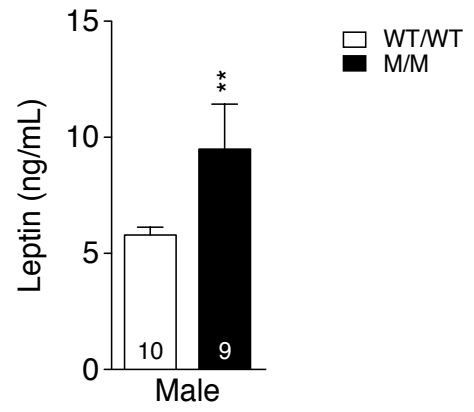

J

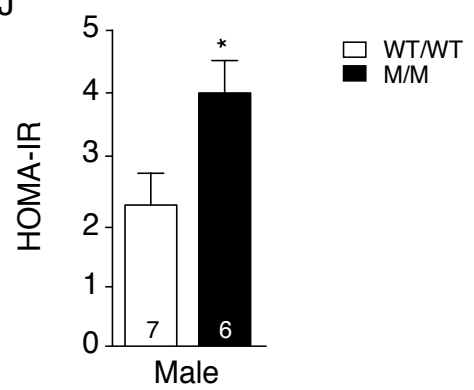

B

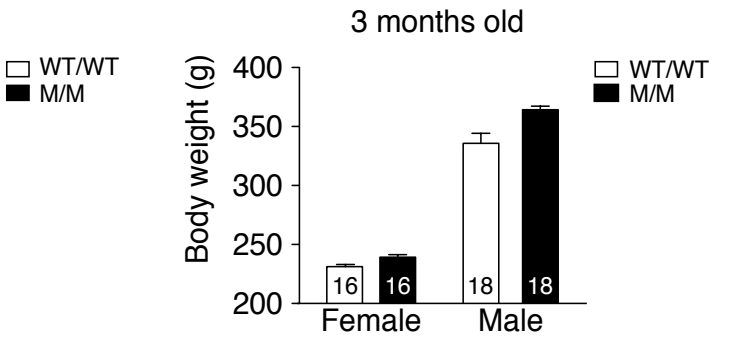

E

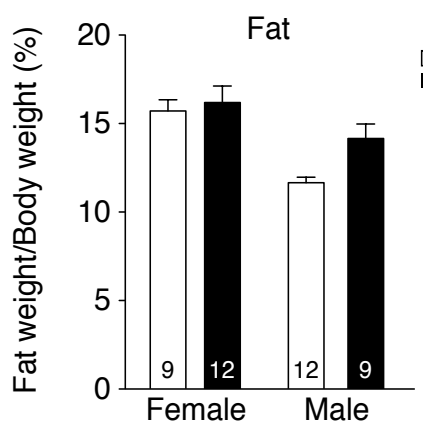

$\mathrm{H}$

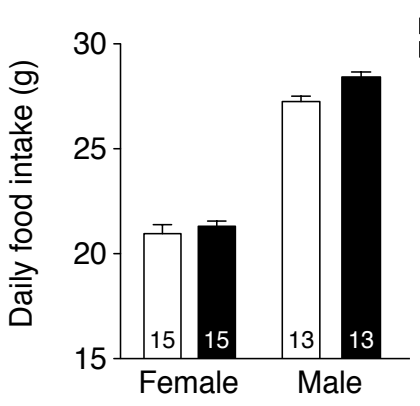

K

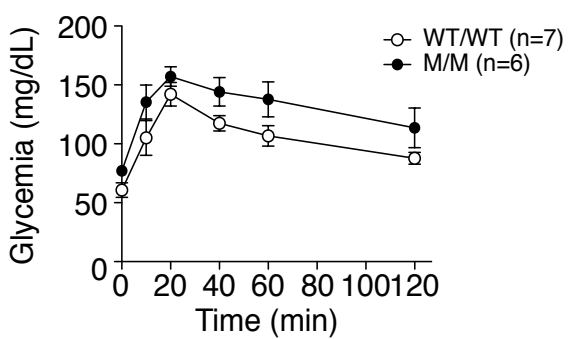

C

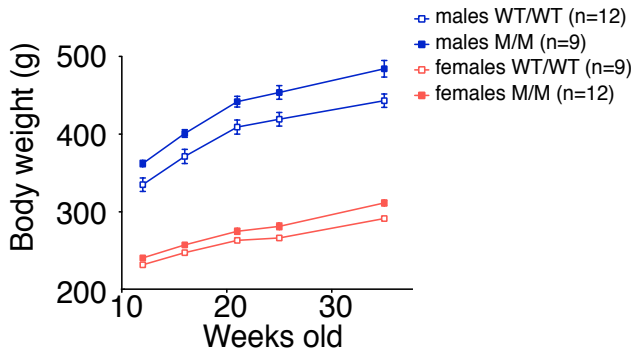

F

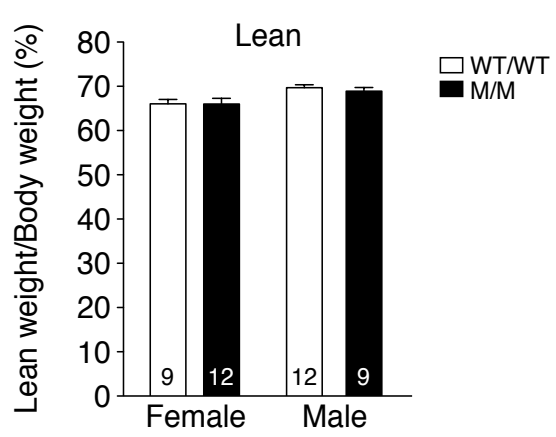

I

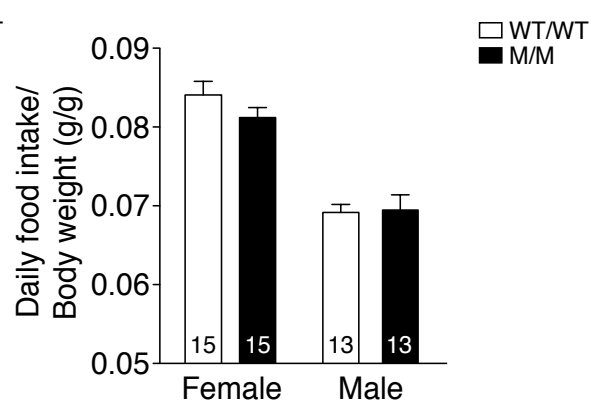

L

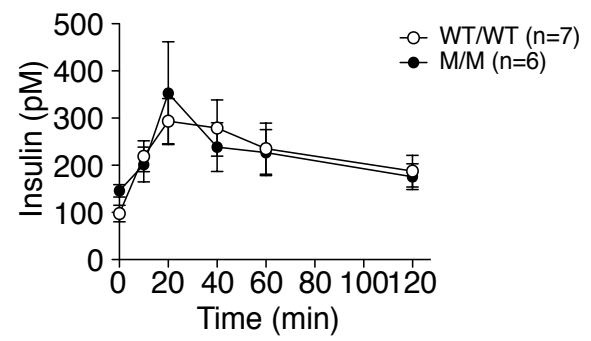

Fig. 5 


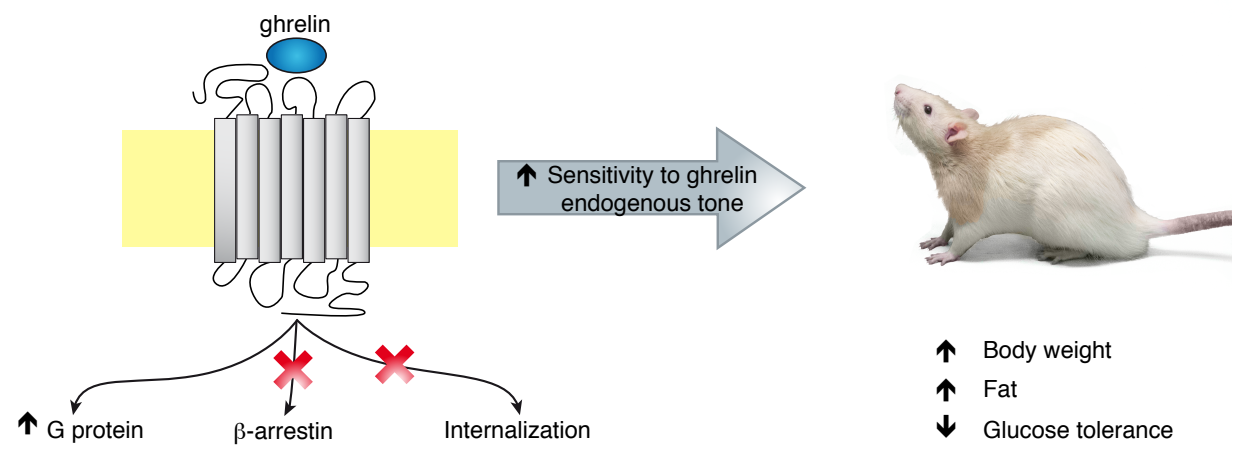

Fig. 6 